\title{
Environmental controls on benthic food web functions and carbon resource use in subarctic lakes
}

\author{
Kivilä, E. Henriikka
}

2019-04

Kivilä, E H , Luoto , T P , Rantala , M V , Kiljunen, M , Rautio , M \& Nevalainen , L 2019 , ' Environmental controls on benthic food web functions and carbon resource use in subarctic lakes ' , Freshwater Biology , vol. 64 , no. 4 , pp. 643-658 . https://doi.org/10.1111/fwb.13250

http://hdl.handle.net/10138/326140

https://doi.org/10.1111/fwb.13250

acceptedVersion

Downloaded from Helda, University of Helsinki institutional repository.

This is an electronic reprint of the original article.

This reprint may differ from the original in pagination and typographic detail.

Please cite the original version. 


\section{Environmental controls on benthic food web functions and carbon resource use in subarctic lakes}

Short title: Benthic feeding functionality and resources

E. Henriikka Kivilä ${ }^{1}$, Tomi P. Luoto ${ }^{2}$, M arttiina V. Rantala ${ }^{3}$, M ikko Kiljunen $^{1}$, M illa Rautio ${ }^{4} \&$ Liisa Nevalainen ${ }^{2}$

${ }^{1}$ Department of Biological and Environmental Science, University of Jyväskylä, Jyväskylä, Finland

${ }^{2}$ Faculty of Biological and Environmental Sciences, Ecosystems and Environment Research Programme, University of Helsinki, Lahti, Finland

${ }^{3}$ Institute of Earth Surface Dynamics, University of Lausanne, UNIL M ouline, 1015 Lausanne, Switzerland

${ }^{4}$ Département des Sciences Fondamentales, Université du Québec à Chicoutimi, Canada, Groupe de Recherche Interuniversitaire en Limnologie et en environnement aquatique (GRIL) and Centre for Northern Studies (CEN)

Key words: organic carbon, Chironomidae, functional ecology, paleolimnology, stable isotopes

Corresponding author: E. Henriikka Kivilä, henriikka.kivila@jyu.fi, Department of Biological and Environmental Science, PO Box 35, 40014 University of Jyväskylä, Finland 


\section{Summary}

1. Climate warming and consequent greening of subarctic landscapes increase the availability of organic carbon to the detrital food webs in aquatic ecosystems. This may cause important shifts in ecosystem functioning through the functional feeding patterns of benthic organisms that rely differently on climatically altered carbon resources.

2. 25 subarctic lakes in Finnish Lapland across a tree line ecotone were analysed for limnological and optical variables, carbon $\left(\delta^{13} \mathrm{C}\right)$ and nitrogen $\left(\delta^{15} \mathrm{~N}\right)$ stable isotope $(\mathrm{SI})$ composition of surface sediment organic matter (OM) and fossil Chironomidae (Diptera) remains to examine environmental controls behind chironomid functional feeding group (FFG) structure and their isotopic associations for assessing ecosystem functioning and carbon utilization. We hypothesize that the chironomid SI signatures reflect increased allochthony with increasing allochthonous input, but the resource use may be altered by the functional characteristics of the assemblage.

3. Multivariate analyses indicated that carbon geochemistry in the sediments $\left(\delta^{13} \mathrm{C}, \delta^{15} \mathrm{~N}, \mathrm{C} / \mathrm{N}\right)$, nutrients, indices of productivity (Chlorophyll-a) and lake water optical properties, related to increasing presence of OM, played a key role in defining the chironomid FFG composition and isotopic signatures.

4. Response modelling was used to examine how individual FFGs respond to environmental gradients. They showed divergent responses for OM quantity, dissolved organic carbon (DOC) and nutrients between feeding strategies, suggesting that detritivores and filter feeders prefer contrasting carbon and nutrient conditions, and may thus hold paleoecological indicator potential to identify changes between different carbon fluxes.

5. Benthic production was the primary carbon source for the chironomid assemblages according to a three-source stable isotope mixing model, whereas pelagic and terrestrial components contributed less. Between-lake variability in source utilization was high and controlled primarily by allochthonous OM inputs. 
6. Combination of biogeochemical modelling and functional classification is useful to widen our understanding of subarctic lake ecosystem functions and responses to climate-driven changes in limnology and catchment characteristics for long-term environmental change assessments and functional paleoecology.

\section{Introduction}

Increasing inputs of terrestrial carbon into freshwaters from catchment surface soils, vegetation (Tranvik et al. 2009) and thawing permafrost (Vonk et al. 2015) are considered a major challenge to Arctic lake ecosystems. Consequent increases in levels of dissolved organic carbon (DOC), coloured dissolved organic matter (CDOM) and nutrient loads have a high potential to alter many biochemical and physical lake characteristics (Jansson et al. 2007; Karlsson et al. 2009). These characteristics include changes in light climate, UV attenuation and thermal regimes, which control primary production and affect the balance between pelagic and benthic producers. DOC input may also enhance heterotrophic production (e.g. Karlsson et al. 2009). As a result, altered carbon pools might affect the amount of energy and quality of nutrition available for lake fauna, which may have consequences for species distribution and eventually for the whole food web structure and its functions (Solomon et al. 2011). Changes in Arctic freshwater systems have global implication through their tight connections to the active carbon cycle, as they play a key role in sequestering and conveying carbon from the terrestrial environment into the atmosphere (Battin et al. 2009). Therefore, it is important to understand how small and shallow Arctic lakes function under natural environmental variability and anthropogenic environmental stresses, such as climate warming.

The benthic zone is often the most productive part of shallow Arctic lakes (Bonilla, Villeneuve \& Vincent 2005) and benthos has been recognized as an integrated part of the aquatic food web (Karlsson et al. 2009; Vadeboncoeur, Vander Zanden \& Lodge 2002; Rautio \& Vincent 2006). In Arctic lakes chironomids (Diptera: Chironomidae) are a crucial component of the benthic fauna, playing a key role in processing OM and 
recycling nutrients (Wallace \& Webster 1996; Vanni 2002). Chironomid fossils preserve well in lake sediments, and their communities are sensitive to various environmental factors, such as temperature, oxygen saturation, lake depth and nutrients, which control their abundance and taxonomic distribution, consequently making them a useful tool for paleoecological studies (Walker 2001; Luoto 2011; Eggermont $\&$ Heiri 2012). However, environmental controls affecting their feeding behaviour and its plasticity are less known. The ability to adjust feeding to the availability of carbon sources would make chironomids sensitive to increasing OM inputs, and leave traces of such changes in the paleolimnological archives.

Functionality of taxa (e.g. feeding habits), rather than just their taxonomic composition, may better define ecosystem functions and responses to environmental changes. Recently, functional aspects have been increasingly incorporated into ecological research, including studies of macrozoobenthos especially in riverine systems (Johnson, Goedko op \& Sandin 2004; Heino 2008; Dolédec \& Statzner 2010). However, our knowledge of chironomid functional traits still includes considerable gaps (Heino 2008; Serra et al. 2016). Chironomid larvae can be divided into several different functional feeding groups (FFGs), from detritivores to predators. The explanatory factors governing feeding mode are considered to be larval body size, food quality and sediment composition (Berg 1995; M erritt, Cummins \& Berg 2008). Chironomids are also often considered opportunistic omnivores due to high levels of plasticity in their feeding mode, which may change according to larval stage and external conditions (Berg 1995; Mihuc 1997; Reuss et al. 2013). Although the functional approach may give essential information about ecosystem functions (GregoryEaves \& Beisner 2011), it has been rarely applied to paleoecology. As an example, it has been used to examine connections between climate fluctuations and large scale patterns of midge functional assemblage composition and diversity (Luoto \& Nevalainen 2015). Increased understanding of changes in functional ecology of the benthic community, triggered by extrinsic environmental variables, would improve our understanding of how lakes and their biota may face global change, including temperature increase and altered carbon fluxes. 
Stable isotopes (SI) are a well-established tool for food web studies and widely used in ecology to disentangle trophic relationships and significance of different nutritional sources consumed by organisms (Peterson \& Fry 1987; Post 2002). SI analytics are increasingly applied in paleolimnological studies by analysing chitinous remains of aquatic invertebrates (Perga 2010; van Hardenbroek et al. 2010, 2012, 2016). For chironomid fossils, the focus has been on carbon isotopes directly associated with food sources, and the method has been used especially for tracing changes in methane emissions over long time periods (van Hardenbroek et al. 2012, 2013; Belle et al. 2016). A growing number of applications reflecting carbon dynamics during lake trophic regime shifts, oxygen depletion and implications for feeding behaviour have emerged (Frossard et al. 2014; Belle et al. 2017a b). Investigation of fossil food webs greatly benefit from incorporating other SIs, such as those of nitrogen, and functional approaches to the carbon SI analysis, leading to more detailed insight on nutrition consumption and trophic interactions in space and time.

Changes in balance between carbon sources, carbon assimilation, and their environmental controls can alter ecosystem functioning and consequently the role of freshwaters in carbon sequestration (e.g. Seekell et al. 2015; Solomon et al. 2015). Hence, identifying contributions of allochthonous and autochthonous carbon is a key question in aquatic feeding ecology (Tanentzap et al. 2017). The quantity and quality of allochthonous carbon input is largely dependent on catchment vegetation and associated variability in soil chemistry (M ichalzik et al. 2001; Aitkenhead-Peterson, M cDowell \& Neff 2003). Therefore, it is particularly important to compare ecotonal lakes that encompass large eco-climatic gradients. In this study, we aim to improve understanding of carbon incorporation from different sources into the benthic food web, and how the process is related to extrinsic (environmental) and intrinsic (functional) attributes. Our specific aims are, firstly, to determine SI signatures of fossil chironomid assemblages and elucidate potential source contribution of pelagic, benthic and terrestrial carbon pools with linkages to environmental variables and vegetation zones in 25 ecotonal lakes across the northern tree line in Finnish Lapland. Secondly, we aim to determine the FFG composition of chironomid assemblages to decipher their relations with carbon source contributions and environmental controls between lakes. We hypothesize that the chironomid SI values 
reveal increased allochthony with increasing allochthonous input reflected as higher proportion of DOC and chromophoric substances, but the functional characteristics of chironomids may alter resource use. We also presume that the FFGs respond uniquely to environmental gradients across the tree line and that the functional classification may retain paleoecological indicator potential.

\section{Methods}

A surface sediment data set comprising 25 small and shallow (max depth 0.5-6.3 m, Table 1.) ecotonal lakes was collected from northern Finland $\left(68-70^{\circ} \mathrm{N}\right)$ in late summer 2014 (Fig. 1). The sites form a geographical S-N transect and were chosen to represent large environmental gradients, including varying humic content and catchment vegetation change across the northern tree line from pine dominated forest to barren tundra. Wetlands are also common in the region. The study area features subarctic climate (mean annual air temperature $-2^{\circ} \mathrm{C}$, precipitation $450 \mathrm{~mm} / \mathrm{y}$ ), with a $\sim 1^{\circ} \mathrm{C}$ gradient in temperature.

A Limnos gravity corer was used to sample sediments $(0-2 \mathrm{~cm})$ from central lake basins. To determine OM quantity and carbon source mixture for the sediments (M eyers \& Teranes 2001), we analysed the amount (Loss-on-ignition at $\left.550^{\circ}, \mathrm{LOI}\right)$, elemental $(\mathrm{C}, \mathrm{N})$ and isotopic $\left(\delta^{13} \mathrm{C}_{\mathrm{OM}}\right.$ and $\left.\delta^{15} \mathrm{~N}_{\mathrm{OM}}\right)$ composition of the sediment organic matter as described in Rantala et al. (2016b). Chl-a concentration of sediment was measured following Nusch (1980). $1-3 \mathrm{~cm}^{3}$ of sediment per sample was extracted three times in $90 \%$ ethanol, filtered $(0.2 \mu \mathrm{m})$, and analysed spectrophotometrically. The results were normalized with the sediment dry weight.

Stable isotope analysis (SIA) of carbon and nitrogen from chironomid head capsules $\left(\delta^{13} \mathrm{C}_{\mathrm{HC}}\right.$ and $\left.\delta^{15} \mathrm{~N}_{\mathrm{HC}}\right)$ was performed following previously established methodology (van Hardenbroek et al. 2010; Heiri, Schilder \& Hardenbroek 2012). M ild acid and base pre-treatments were omitted as both sediment deflocculation and carbonate removal (detected with negligible LOI 950') were considered unnecessary, hence, the 
chironomid Sl signatures represent natural decay. Subsamples of the surface sediments were sieved through a $100 \mu \mathrm{m}$ mesh, thoroughly rinsed with ultrapure water, and chironomid head capsules were handpicked with forceps from the residue under a stereo microscope (x40) into a drop of ultrapure water on an aluminium dish. The head capsules were picked as bulk assemblages due to low concentration and high diversity of morphotypes, which did not favour higher taxonomic specificity in the current analysis. Samples were then dried in an oven $\left(40^{\circ} \mathrm{C}\right)$ to remove excess moisture and transferred into pre-weighed tin cups for SIA. The capsules were dried in an oven $\left(40^{\circ} \mathrm{C}\right)$ overnight to remove all residue moisture, reweighed, closed and stored in a desiccator until analysis. Samples composed of 200-550 individual remains to reach required dry sample mass $(0.2-0.4 \mathrm{mg})$. SIA was performed with a FlashEA 1112 elemental analyser coupled with a Thermo Finnigan DELTA plus Advantage mass spectrometer (Thermo Electron Corporation, Waltham, MA, USA). The SI values are expressed as delta notations $\delta=\left(R_{\text {sample }} / R_{\text {standard }}-1\right) x$ 1000 , where $\mathrm{R}={ }^{13} \mathrm{C} /{ }^{12} \mathrm{C}$ or ${ }^{15} \mathrm{~N} /{ }^{14} \mathrm{~N}$ and standardised to VPDB for carbon and atmospheric concentration for nitrogen. Also, the differences between chironomid and sediment OM isotopic values (e.g. for carbon $\left.\Delta \delta^{13} \mathrm{C}=\delta^{13} \mathrm{C}_{H C}-\delta^{13} \mathrm{C}_{O M}\right)$, were calculated for each sample and are later referred to as isotopic offsets $\left(\Delta \delta^{13} \mathrm{C}\right.$ and $\left.\Delta \delta^{15} \mathrm{~N}\right)$. They show chironomid discrimination from the bulk $\mathrm{OM}$ and indicate level of selectivity between sedimentary carbon pools. As selectivity indices, we use the absolute value of $\Delta \delta^{13} \mathrm{C}$ and $\Delta \delta^{15} \mathrm{~N}$, to focus on the level of discrimination.

Results for taxonomic analysis of fossil chironomid assemblages from the same sediment samples are presented and discussed in Luoto et al. (2016). In this study, each taxon was assigned a FFG (M andaville 2002; Merritt, Cummins \& Berg 2008). Four groups were present in the data: collector-gatherers (C-G), collector-filterers (C-F), shredders (SHR) and predators (PRD) and a list of taxa grouped into each FFG is available in Appendix 1. Relative abundance (\%) of each FFG of the total assemblages was calculated for each study lake. 
Water samples were collected from the epilimnion for analysis of total nitrogen (TN), total phosphorus (TP), chlorophyll-a (Chl-a), DOC and CDOM concentrations. CDOM concentration is a combination of humic components $(1-5,6)$ from PARAFAC analysis. In situ field measurements involved pH and photosynthetically active radiation (PAR) profiling, which gives indication on the level of primary production. These analyses are thoroughly described in Rantala et al. (2016b) and Nevalainen et al. (2015). A summary of selected limnological and sediment biochemical variables is presented in Table 1.

A three-source (pelagic, benthic and terrestrial) SI mixing model was calculated with package simmr (Parnell \& Inger 2016) in R 3.4.0 (R Core Team 2017). Values for end-member estimates were collected from literature (Appendix 2) with preference for measurements from lakes in the same region. We used benthic mat and biofilm values to detect the benthic signal (mean $\pm S D$ : $\delta^{13} \mathrm{C}=-21.1 \pm 3.7, \delta^{15} \mathrm{~N}=0.7 \pm 1.3$ ), zooplankton values to trace pelagic signal (mean $\delta^{13} \mathrm{C}=-32.1 \pm 1.6, \delta^{15} \mathrm{~N}=3.8 \pm 1.3$ ), and a mixture of terrestrial leaves, litter and soil for determining terrestrial signal (mean $\delta^{13} \mathrm{C}=-28.3 \pm 1.1, \delta^{15} \mathrm{~N}=-1.7 \pm 2.9$ ). Fractionation correction coefficients $( \pm \mathrm{SD})$ of $0.50 \pm 0.56 \%$ and $1.5 \pm 0.50 \%$ for carbon and nitrogen, respectively, were applied to benthic and terrestrial sources to account for trophic enrichment (Goedkoop, Åkerblom \& Demandt 2006).

To explore bivariate relationships within the data, Spearman's rank correlations $(\rho)$ were calculated. Linear models (ordinary least squares) were used for further investigation of the isotopic relationships and variance analyses (ANOVA, Kruskal-Wallis) were used for comparing mean source contribution groups between vegetation zones (shown in Fig. 1.). These analyses were performed with PAST 3.0 (Hammer, Harper \& Ryan 2001). For multivariate analyses, we used $\delta^{13} \mathrm{C}_{\mathrm{OM}}, \delta^{15} \mathrm{~N}_{\mathrm{OM}}$, depth, pH, C/N, Chl-a_s, LOI, DOC, KdPAR, N/P, Chl-a, Colour, SUVA and Cat/Lake (see Table 1 for abbreviations) as the set of environmental variables (inflation factor $<25$ ). Redundancy analysis (RDA) was used for exploring relationships between environmental variables (Table 1$)$ and (1) chironomid Sl values $\left(\delta^{13} \mathrm{C}_{\mathrm{HC}}, \delta^{15} \mathrm{~N}_{\mathrm{HC}}\right)$ and isotopic offsets $\left(\Delta \delta^{13} \mathrm{C}\right.$, $\Delta \delta^{15} \mathrm{~N}$ ), (2) chironomid FFGs, and (3) potential carbon sources. The data were $\log _{10}$ transformed for 
standardization and a constant was added to variables with negative values prior to transformation. A suite of ecologically meaningful environmental variables with inflation factor $<25$ were chosen for the analysis and further identification of significant variables was based on forward selection with 999 M onte Carlo permutations. FFG response models for selected ecologically relevant environmental variables (LOI, DOC, depth and N/P -ratio) were calculated as RDA based generalized linear models (GLM) with predictor form set to quadratic fit and response distribution to Poisson. Response data were $\log _{10}$ transformed prior to analysis. All multivariate analyses were produced with Canoco 5 (ter Braak \& Šmilauer 2012).

\section{Results}

High between-lake diversity was observed in FFG distribution (Fig. 2.). Collector-gatherers (C-G) were the most common feeding group with a mean abundance of $46 \%$, followed by collector-filterers (C-F, $33 \%$ ), shredders (SHR, $13 \%$ ) and predators (PRD, $8 \%$ ). Highest variability was observed within SHR, ranging 0$69 \%$ between lakes, and lowest within PRD constituting 2-18\% of assemblages. Of the 25 lakes, 15 lakes were dominated by C-G and 8 lakes by C-F groups. Two lakes $(\# 21,23)$ were dominated by SHR, while PRD occurred in all lakes in small quantities. All lakes but one (\#8) featured all four FFGs and their relative proportions varied markedly between lakes.

The SI values of fossil chironomid assemblages showed variation ranging between $-20.4 \%$ and $-34.4 \%$ for $\delta^{13} \mathrm{C}$ and between $4.6 \%$ and $0.3 \%$ for $\delta^{15} \mathrm{~N}$ (Table 1, Fig. 3A, C). The $\delta^{13} \mathrm{C}_{\mathrm{HC}}$ values were consistently more ${ }^{13} \mathrm{C}$-depleted than $\delta^{13} \mathrm{C}_{\mathrm{OM}}$, while $\delta^{15} \mathrm{~N}_{\mathrm{HC}}$ were more positive than $\delta^{15} \mathrm{~N}_{\mathrm{OM}}$, however, the difference showed considerable variation between lakes. As the direction within each offset is the same $\left(\Delta \delta^{13} \mathrm{C}\right.$ negative and $\Delta$ $\delta^{15} \mathrm{~N}$ positive), we concentrate only on the level of offset in the following, and hence use the absolute values of isotopic offsets. Accordingly, absolute values of $\Delta \delta^{13} \mathrm{C}$ and $\Delta \delta^{15} \mathrm{~N}$ varied between $0.4-3.4 \%$ and $1.7-3.3 \%$ respectively (Fig. 3B, D). 
Spearman's correlations $(\rho)$ between the chironomid SI signatures and environmental variables revealed strong relationships with limnological and sediment quality variables (Table 2). Sediment and chironomid SI values were strongly positively correlated (Table 2., Fig. 3A, C). The offset - sediment OM relationships were much weaker with divergent directions for $\mathrm{C}$ and N (Fig. 3B, D), showing a positive and negative correlation, respectively, and lower coefficients of determination.

The SI mixing model showed that samples were distributed within the area defined by the source estimates on isospace plot (Fig. 4.) For the whole lake set, SI mixing model showed the benthic source dominant (mean $=44 \%, S D=0.075)$, followed by pelagic $(29 \%, 0.062)$ and terrestrial $(27 \%, 0.072)$ components, with high between-lake variability (Fig. 5.). When comparing the mean source contributions between ecoregions (Fig. 1.), there were no significant differences between the tundra and mountain birch woodland for any source, however, there were significant differences between lakes below (\#2-12, n =9) and above (\# 1434, $n=16$ ) the pine limit (Fig. 5.) when tundra and mountain birch woodland were pooled. The benthic carbon contribution was relatively more dominant in lakes north of the pine limit than south of it (KruskalWallis $\mathrm{chi}^{2}=4.04, \mathrm{p}=0.044$ ), whereas pelagic component had marginally higher importance in the north boreal type lakes south of the pine limit. Terrestrial component differed significantly across the pine limit (anova $F_{1,23}=4.59, p=0.043$ ), although its contribution had less variability than the others (Fig. $5 C$ ), and was strongly linked to wetland coverage through significant $(p<0.05)$ correlations with the carbon optical variables (Table 2, Fig. 6C) and sediment composition (C \%, $\rho=0.50 ; \mathrm{N} \%, \rho=0.56$ ). Other significant correlations showed that pelagic component is favoured in deeper lakes, and that $\mathrm{C} / \mathrm{N}$ ratio has fairly strong, convergent trends with benthic and pelagic sources (Table 2).

Full RDA model for FFG-environment relationships $\left(\lambda_{1}=0.37, \lambda_{2}=0.20\right)$ explained $69.5 \%$ of variance (Fig. $6 A)$. Significant $(p<0.05)$ environmental variables identified with forward selection were Chl-a_s $(14.2 . \%)$, $\delta^{13} \mathrm{C}_{\mathrm{OM}}\left(11.1 \%\right.$ ) and depth (8.9\%), which together explained $34.2 \%$ (adjusted $24.8 \% ; \lambda_{1}=0.18, \lambda_{2}=0.13$ ). RDA model for examining chironomid SI signatures and offsets with a full set of sedimentary and 
limnological parameters $\left(\lambda_{1}=0.39, \lambda_{2}=0.21\right)$ explained $83.7 \%$ of the variance (Fig. 6B). Based on forward selection, the significant explanatory variables were $\delta^{13} \mathrm{C}_{\mathrm{OM}}(35.1 \%), \delta^{15} \mathrm{~N}_{\mathrm{OM}}(21.8 \%), \mathrm{C} / \mathrm{N}(6.9 \%)$ and $\operatorname{kdPAR}(4.9 \%)$, which together accounted for $68.7 \%$ (adj. $62.4 \% ; \lambda_{1}=0.38, \lambda_{2}=0.20$ ) of variance. The full RDA model explaining carbon sources with environmental variables $\left(\lambda_{1}=0.77, \lambda_{2}=0.15\right)$ explained $94.6 \%$, while forward selection picked out $\delta^{13} \mathrm{C}_{\mathrm{OM}}(73.9 \%)$, LOI (6.6 \%), SUVA (3.7 \%) Cat/Lake $(2.2 \%)$ and Colour (1.7\%), altogether explaining $88.1 \%$ (adj. 85.0\%; $\left.\lambda_{1}=0.75, \lambda_{2}=0.15\right)$ (Fig 6C). The strength of ecological relevance of each environmental variable was explored with single variable constrained RDAs, which indicate that the most relevant $\left(\lambda_{1} / \lambda_{2}>0.8\right)$ relationships for chironomid SI signatures are $\delta^{13} C_{O M}$ and $\delta^{15} \mathrm{~N}_{\text {OM }}$, while for the sources $\delta^{13} \mathrm{C}_{\mathrm{OM}}$ is most relevant.

FFG response curves for carbon quantity (substrate and dissolved), nutrients and depth (Fig. 7) revealed that there were divergent preferences between the major feeding strategies (C-G and C-F) and selected limnological variables. Detritivores (C-G) preferred shallowest lakes with highly organic substrate and tolerated better higher DOC and N load, whereas filter feeders (C-F) preferred lakes 4-5 m deep and LOI of ca. $50 \%$. They preferred a lower N/P ratio and had a positive response to both ends of DOC concentration. SHR preferred low (<40\%) and weakly very high ( $>80 \%)$ sediment OM quantity and preferred deeper water. For PRD there were no clear relationships.

\section{Discussion}

Functional feeding behaviour and its relation to environmental variables

The subarctic lakes in Finnish Lapland feature dominance of benthic over pelagic production (Rantala et al. 2016b) and retain diverse communities of benthic invertebrates, including chironomids (Luoto et al. 2016). Our results show that generalist feeding strategies amongst chironomids were beneficial for survival in the 
lakes, as collectors (C-G and C-F) were dominant, while specialized FFGs (PRD and SHR) were less abundant. This is typical of high-latitude lake food webs with low biocomplexity (Christoffersen et al. 2008). As exceptions, two lakes (\#21\& \#23) featured a high dominance of shredders (SHR), reflecting the availability of adequate nutrition sources and habitats likely associated with aquatic macrophytes. Collectors tend to be omnivorous, consuming all suitable sized particles (Cummins \& Klug 1979), which allows them to adapt to various food sources. The relative distribution of filter-feeders (C-F) and detritivores (C-G) was associated with the sediment OM quantity (LOI), C-F being more abundant in low organic content and C-G preferring high organic content. This agrees with previous studies stating that substrate quality or LOI is one of the driving factors of taxonomic chironomid diversity in lakes (Nyman, Korhola \& Brooks 2005; Heino 2008; Luoto et al. 2016). This relationship was clear also in our FFG response models, where C-G preferred shallow systems with organic rich substrate (high benthic production), while C-F opted for medium depth and OM quantity in the sediment. High abundance of C-Fs is likely associated with increased pelagic production as food source, which is also supported by their preference for low DOC and N/P ratio, as phytoplankton is typically phosphorus limited. Instead, mat-forming benthic communities are less dependent on dissolved phosphorus, as they circulate nutrients internally (Bonilla et al. 2005). C-Gs on the other hand preferred higher DOC, as well as higher N/P ratio, where increased nitrogen was most likely associated with increased terrestrial input (Rantala et al. 2016b). The FFG response models suggests that CFs and C-Gs respond strongly and in a different manner to carbon and nutrient gradients and thus have specific but opposing habitat preferences. Accordingly, different habitat preferences may be useful indicators for paleolimnological studies, as C-Fs prefer oligotrophic clear water conditions and C-Gs organic rich substrates tolerating dark water colour better.

A multitude of environmental factors shapes the taxonomic and functional diversity, distribution and composition of macrobenthic fauna on various scales. Luoto \& Nevalainen (2015) concluded that both spatial and temporal changes in midge FFG distribution are driven by climatic controls, primarily temperature, on local-scale factors. Luoto et al. (2016) identified LOI, TN, pH and water depth as the 
significant environmental variables driving taxonomic chironomid distribution in northern Finland, while we found $\delta^{13} \mathrm{C}_{\mathrm{OM}}$, depth and Chl-a_s significant for FFG distributio. Both taxonomic and functional approaches thus identified factors related to productivity among the most influential, yet divergent forcers prevailed for taxonomic versus functional groups. Interestingly, LOI was not a significant variable in our RDAs. However, significant for the FFGs were $\delta^{13} C_{O M}$, indicating the origin of OM (Meyers $\&$ Teranes 2001), and sedimentary Chl-a, representing a combination of pelagic and benthic production and likely reflecting the latter more closely due to source proximity. This suggests that OM quality plays an important role for FFG composition. Water depth is a well-known indirect factor affecting taxonomic chironomid diversity (Korhola, Olander \& Blom 2000) and its effects on chironomid functionality are related to different habitats and altered substrate quality along a depth gradient.

Isotopic signatures of chironomids

Several studies have previously noted that chironomid carbon SI signatures are closely associated with those of sediment OM (e.g. Wooller, Wang \& Axford 2008; van Hardenbroek et al. 2013; Belle et al. 2017a), which is evident also in our data. Chironomid nitrogen Sls have been widely applied in ecological studies of living larvae (e.g. Grey, Kelly \& J ones 2004; Chételat, Cloutier \& Amyot 2010; Bartels et al. 2012a; Reuss et al. 2013), but rarely in paleolimnological approaches (Griffiths et al. 2010). Typically, our $\delta^{15} \mathrm{~N}_{\mathrm{HC}}$ enrichment relative to $\delta^{15} \mathrm{~N}_{\mathrm{OM}}$ values (mean $\pm \mathrm{SD} 2.50 \pm 0.45 \%$ ) reflect trophic fractionation (Vander Zanden \& Rasmussen 2001), whereas $\delta^{13} \mathrm{C}_{\mathrm{HC}}$ values were more ${ }^{13} \mathrm{C}$-depleted than $\delta^{13} \mathrm{C}_{\mathrm{OM}}(-1.48 \pm 0.80 \%$ ), likely due to selective ingestion or assimilation of preferred components rather than bulk OM (Doi, Katano \& Kikuchi 2006; Solomon et al. 2008). The $\delta^{13} C_{H C}$ values showed variation of over $14 \%$ (from -34.36 to $-20.38 \%$ ), covering a range of typical allochthonous and autochthonous production (France 1995; M eyers \& Teranes 2001), and had a strong positive relationship with $\delta^{13} \mathrm{C}_{\mathrm{OM}}$. This indicates significance of sedimentary carbon in the chironomid diet and agrees with the observed FFG patterns, where detritus feeding strategies were dominant. The $\delta^{15} \mathrm{~N}_{\mathrm{HC}}$ (ranging over $4.36 \%$ ) had a relationship with $\delta^{15} \mathrm{~N}_{\mathrm{OM}}$ nearly as high as for carbon, 
suggesting a strong dependence on the variation within isotopic base level of the nutrition, and a weaker connection to the trophic dynamics for the $\delta^{15} \mathrm{~N}_{\mathrm{HC}}$. Lake depth also had a strong relationship with $\delta^{15} \mathrm{~N}_{\mathrm{HC}}$, likely through the connection between $\delta^{15} \mathrm{~N}_{\mathrm{HC}}$ and $\delta^{15} \mathrm{~N}_{\mathrm{OM}}$. Rantala et al. (2016b) suggested that reduction of benthic production in deeper waters may partially explain the ${ }^{15} \mathrm{~N}$-enriched $\delta^{15} \mathrm{~N}_{\mathrm{OM}}$. Accordingly, $\delta^{13} \mathrm{C}_{\mathrm{HC}}$ is affected through similar changes in carbon composition along a depth gradient becoming more ${ }^{13} \mathrm{C}$ depleted in deeper waters (Solomon et al. 2008).

The isotopic carbon offset $\Delta \delta^{13} \mathrm{C}$ between the lakes varied over almost $3 \%$, indicating differences in the level of selectivity of chironomid feeding between sites. It has been previously shown that chironomids (Bartels et al. 2012a; Belle et al. 2017a) and aquatic insects in general (Marcarelli et al. 2011) select for higher quality nutrition. In our results $\Delta \delta^{13} \mathrm{C}$ tended to be higher when the $\delta^{13} \mathrm{C}_{\mathrm{OM}}$ was less ${ }^{13} \mathrm{C}$-depleted, suggesting that feeding selectivity is higher in conditions with higher proportion of carbon from terrestrial sources or benthic production in the sediment. This may be related to discriminating against allochthonous or poor quality organic components either in ingestion or assimilation. It may also be connected to the presence of rich benthic algal and bacterial production, where a variety of autochthonous resources of different nutritional quality is easily available, thus creating a situation where highly selective foraging strategy is easy and cost-efficient.

For the $\Delta \delta^{15} \mathrm{~N}$ and $\delta^{15} \mathrm{~N}_{\text {OM }}$, a weaker inverse relationship was observed. Although the relationship was less clear than for carbon, the pattern where higher $\Delta \delta^{15} \mathrm{~N}$ is associated with lower $\delta^{15} \mathrm{~N}_{\text {OM }}$ support feeding preference for the isotopically more ${ }^{15} \mathrm{~N}$-enriched autochthonous sediment fraction, such as benthic algae, over poorer quality nutrition, such as bacteria or terrestrial resources. Besides diet quality (Post 2002; M cCutchan et al. 2003; Vanderklift \& Ponsard 2003), nitrogen isotopes discrimination can also increase, for instance, by starvation of the fauna (Hobson, Alisauskas $\&$ Clark 1993) or nitrogen limitation of the algae (Vander Zanden \& Rasmussen 2001) they feed on. The trophic N enrichment for chironomids is smaller (ca $1.5 \%$, Goedkoop et al. 2006) than $3.4 \%$ generally considered a standard in food web studies (M inagawa 
\& Wada 1984; Vander Zanden \& Rasmussen 2001; Post 2002). The combination of our bulk assemblage approach and low numbers of predatory chironomids may result in challenges distinguishing positive relationships between higher $\Delta \delta^{15} \mathrm{~N}$ values and assemblages with larger proportion of predators, even though our $\Delta \delta^{15} \mathrm{~N}$ range is wide enough to accommodate several trophic levels. Partly for the same reason, all isotopic relationships directly with the FFGs are difficult to interpret and impossible to quantify, as our isotopic signatures represent the bulk assemblage while the FFG analysis was performed with a finer resolution. Accordingly, such relationships should be viewed cautiously acknowledging the discrepancy in resolution.

Carbon sources and contributions

SI mixing models may provide valuable information on potential carbon sources for paleoecological studies. Assigning the fractionation coefficient is a challenge for mixing models, as fairly small changes may significantly alter the model outcome (Caut, Angulo \& Courchamp 2009; Bond \& Diamond 2011). Our model appears robust in this regard, as we used a chironomid-specific average for fractionation (Goedkoop et al. 2006) and tested others applicable for aquatic food webs (Vander Zanden \& Rasmussen 2001; McCutchan et al. 2003), which all yielded similar between-lake patterns. Also, the literature-based endmember SI value estimates provide sensible spatio-temporal variability, excluding the problem with sitespecific isotope 'snapshot' of the end-members. They also define a clear area where the observations are located within the isospace plot (e.g. Phillips et al. 2014). It has been shown that Bayesian models are relatively insensitive to variation in the source values if isotopic differences between the end-members are large (Tanentzap et al. 2017). Accordingly, the model is used only for relative across-lake comparisons.

In the study lakes autochthonous material was composed primarily by benthic production (Rantala et al. 2016b), typical of shallow subarctic lakes (Vadeboncoeur et al. 2002; Rautio et al. 2011). Benthic algal and bacterial mats were observed in several of the lakes during sampling while the chl-a values from the water 
column remained low indicating low planktonic production (Rantala et al. 2016b). This agrees with our SI mixing model, which identified benthic sources generally most dominant (mean benthic $>50 \%$ in 10 lakes), especially above the pine tree line. Mean pelagic contribution was less than $25 \%$ in more than half of the lakes, and accordingly, pelagic coupling to the zoobenthos has been previously reported weak in Arctic lakes (Hershey et al. 2006; Chételat et al. 2010). However, the pelagic component appeared highly important in some lakes (mean pelagic $>50 \%$ in 4 lakes). The most ${ }^{13} \mathrm{C}$-depleted $\delta^{13} \mathrm{C}$ values $\left(\delta^{13} \mathrm{C}_{\mathrm{HC}}-34.4\right.$ $\%$ and $\delta^{13} \mathrm{C}_{\mathrm{OM}}-33.8 \%$ ) possibly representing mixed methanogenic signal (e.g. Jones $\&$ Grey 2011 ) instead of sole high pelagic dominance were found in lake $\# 21$, which is a deeper funnel shaped basin likely experiencing bottom anoxia at least part of the year. Although the $\delta^{13} \mathrm{C}_{\mathrm{HC}}$ and $\delta^{13} \mathrm{C}_{\mathrm{OM}}$ values were in the range of pelagic production (Finlay \& Kendall 2007), even lower $\delta^{13} \mathrm{C}$ values $(-39.8 \%$ ) from fossil cladocerans from the same site (Rantala, Luoto $\&$ Nevalainen 2016a) support incorporation of methane oxidizing bacteria into the food web.

We observed a geographical pattern within the source contributions where benthic and terrestrial components differed below and above the coniferous (pine) tree line. A similar pattern can be seen in the pelagic component. Benthic resources are generally dominant in lakes above the pine tree line, whereas pelagic and terrestrial components have higher relative importance below it. While vegetation zones are often identified as significant drivers of lake and sediment chemistry (e.g. Korhola, Weckström \& Blom 2002), Rantala et al. (2016b) found that vegetation zones did not significantly explain the variability of limnology or sediment geochemistry in the study lakes owing to overriding influence of wetland cover. Wetland-related environmental parameters such as CDOM, DOC, and nutrient concentrations do not show clear differences above versus below the pine tree line. However, higher N/P ratio and lower pH below the tree line suggests that the differences in resource use across the tree line may be associated with the quality of allochthonous input. Allochthonous substances originating from cool coniferous forest soils are more acidic (Aitkenhead-Peterson et al. 2003) and bioavailable (Berggren, Laudon \& Jansson 2007) than those from wetlands, which may boost pelagic production in small concentrations and increase 
heterotrophic production, consequently leading to the higher importance of pelagic and terrestrial source contributions.

Depth of the water column was positively linked with the pelagic source contribution, indicating that pelagic food components are preferred when available in deeper lakes. Benthic and pelagic mean source contributions correlated with the $\mathrm{C} / \mathrm{N}$ ratio of $\mathrm{OM}$, suggesting that the relative availability of these resources is reflected in the surface sediment chemistry. The $\mathrm{C} / \mathrm{N}$ relationship to terrestrial source utilization was small and non-significant, which could be an indication that most of the terrestrial carbon is in the dissolved form as DOM (dissolved organic matter) instead of sedimentary forms which would be more available for foraging chironomids. This would highlight the importance of heterotrophic pathways over direct ingestion of allochthonous OM.

Allochthonous input to the study lakes is variable and linked to catchment wetland coverage, which is mirrored at the lakes as higher nutrient loading and increased concentrations of DOC and chromophoric substances (Rantala et al. 2016b). M ean terrestrial source contribution in our mixing model varied from 7 to $53 \%$ between lakes, and was clearly associated with the N/P, DOC and kdPAR as seen by similar ordination directions. Positive correlations of terrestrial contribution with DOC, CDOM and kdPAR showed that allochthony is higher in lakes with higher terrestrial input and lower water transparency as also observed by Solomon et al. (2011). The question of how much allochthonous carbon is capable of supporting the aquatic food webs has been debated (e.g. Cole et al. 2011; Brett et al. 2012, 2017). However, a recent study by Tanenzap et al. (2017) linking allochthony to lake and catchment parameters showed that terrestrially derived resources for lake food webs are important, constituting a minimum of 42 $\%$ in half of the consumer (zooplankton) observations. Our study suggested more modest importance of terrestrial resources in chironomid diet, which is in accordance with experimental studies noting that omnivores are less likely to incorporate terrestrial subsidies (Bartels et al. 2012b), and that while there is a large variability between allochthony amongst benthic organisms, chironomids especially have a low 
reliance on terrestrial OM (Bartels et al. 2012a). These differences are likely linked to the different feeding strategies, which diverge even among detritivores. For instance, during high terrestrial load detritivores feeding directly on the sediment surface incorporate more terrestrial resources, while burrowing chironomids can consume sediment OM from different depths and hence can easily select for better quality nutrition, as suggested by experiments (Bartels et al. 2012a).

Terrestrial carbon is known as poor quality nutrition (Brett et al. 2009) and, while becoming more available through processing by heterotrophic bacteria (Jansson et al. 2000), both the mechanisms and conditions where allochthonous resources serve as an important source supporting the aquatic food web require further investigations. With the RDA, we identified extrinsic variables related to substrate quality and quantity in addition to carbon optical measures to be most significant for determining directly the $\delta^{13} C_{H C}$ and $\delta^{15} \mathrm{~N}_{\mathrm{HC}}$, as well as the relative SI resource contributions. RDA identified water colour and SUVA, which are directly linked to the extent of terrestrial input in the lakes (Weishaar et al. 2003; Rantala et al. 2016b), important for source contributions and kdPAR for the $\delta^{13} \mathrm{C}_{\mathrm{HC}}$ and $\delta^{15} \mathrm{~N}_{\mathrm{HC}}$, indicating that light availability and consequent effects on productivity (Ask et al. 2009; Karlsson et al. 2009; Seekell et al. 2015) affect resource consumption by chironomids. In addition, the drainage ratio (Cat/Lake) was identified significant for the source contributions, likely due to its association with the quality and quantity of catchment inputs through hydrological features.

The tight coupling between primary production (pelagic and benthic) and terrestrial OM through nutrient input and light limitation controls the relative availability of resource pools (Seekell et al. 2015), which is important in guiding consumer resource use in lakes. Allochthonous input can supplement autochthonous resources (Solomon et al. 2008), while it may not be capable of superseding autochthonous components due to weaker nutritional quality (Kelly et al. 2014; Carpenter et al. 2016). It has become evident that the time (e.g. seasonality) or space (e.g. habitat) limited availability of these different resources is directly related to their usage within and between lakes (Tanentzap et al. 2017). Our results suggest that resource 
availability is controlled by environmental attributes, but resource consumption is guided by preference for higher quality nutrition when available.

\section{Conclusions}

Controls over chironomid isotopic signatures, FFGs and nutrition pools used by chironomids appear to be related to the quantity and quality of $\mathrm{OM}$, nutrient load and light climate in the study lakes. Allochthonous input from the catchment exerted a strong control over the levels of nutrients and chromophoric substances, which together with water depth, guided the distribution of FFGs in the lakes. The use of different carbon pools as nutrition sources was dependent on resource availability and quality. The environmental parameters related to carbon, bio-optics and nutrients, controlled resource availability and were crucial in defining the framework where functional differences occur. Chironomids appeared to feed selectively as isotopic discrimination was higher in excess of poor quality food suggesting that different feeding strategies should be considered in studies of macrozoobenthos. Resource use is thus linked to the proportion of available carbon pools in different habitats, but also feeding strategies and level of selectivity implied by the fauna, highlighting the importance of understanding the functional ecology of different food web components, especially among the lower levels of secondary production as the effects are further cascaded in the food web. By applying the functional approach into a paleolimnological context, we open doors for a wider understanding of organic carbon processing by macrobenthic fauna, and its consequent effects for the aquatic ecosystem functions in space and time. Accordingly, functional paleoecology, as defined and applied in the current study by a combination of chironomid functional classification, SIA and mixing models, has potential to disentangle ecosystem functions beyond taxonomic information, and will be particularly interesting when applied to longer timescales covering lake ontogeny and biological adaptations to changing climate. 


\section{Acknowledgements}

Financial support for the work was provided by Doctoral Programme of Biological and Environmental Science of University of Jyväskylä Graduate School for Doctoral Studies, Academy of Finland VIOLET project (\#287547), Emil Aaltonen Foundation (\#160156, \#170161), Doctoral Programme in Geosciences of University of Helsinki, Natural Sciences and Engineering Research Council of Canada, and the Canadian Foundation for Innovation. We thank Annukka Galkin for assistance in the field and in the laboratory, and the personnel of the Kevo Subarctic Research Station for their support during fieldwork. The authors declare no conflict of interest.

\section{References}

Aitkenhead-Peterson J.A., M cDowell W.H. \& Neff J.C. (2003) Sources, Production, and Regulation of Allochthonous Dissolved Organic M atter Inputs to Surface Waters. In: Aquatic Ecosystems: Interactivity of Dissolved Organic Matter. (Eds S.E.G. Findlay \& R.L. Sinsabaugh), pp. 25-70. Elsevier Science (USA).

Ask J., Karlsson J., Persson L., Ask P., Byström P. \& Jansson M. (2009) Terrestrial organic matter and light penetration: Effects on bacterial and primary production in lakes. Limnology and Oceanography 54, 2034-2040.

Bartels P., Cucherousset J., Gudasz C., Jansson M., Karlsson J., Persson L., et al. (2012a) Terrestrial subsidies to lake food webs: An experimental approach. Oecologia $\mathbf{1 6 8 , 8 0 7 - 8 1 8 .}$

Bartels P., Cucherousset J., Steger K., Eklov P., Tranvik L.J. \& Hillebrand H. (2012b) Reciprocal subsidies between freshwater and terrestrial ecosystems structure consumer resource dynamics. Ecology 93, 1173-1182.

Battin T.J., Luyssaert S., Kaplan L. a., Aufdenkampe A.K., Richter A. \& Tranvik L.J. (2009) The boundless 
carbon cycle. Nature Geoscience 2, 598-600.

Belle S., Luoto T.P., Kivilä H.E. \& Nevalainen L. (2017a) Chironomid paleo diet as an indicator of past carbon cycle in boreal lakes: Lake Kylmänlampi (Kainuu province; Eastern Finland) as a case study. Hydrobiologia 785.

Belle S., M illet L., Lami A., Verneaux V., M usazzi S., Hossann C., et al. (2016) Increase in benthic trophic reliance on methane in 14 French lakes during the Anthropocene. Freshwater Biology.

Belle S., Verneaux V., Mariet A.L. \& Millet L. (2017b) Impact of eutrophication on the carbon stable-isotopic baseline of benthic invertebrates in two deep soft-water lakes. Freshwater Biology 62, 1105-1115.

Berg M .B. (1995) Larval food and feeding behaviour. In: The chironomidae: Biology and ecology of nonbiting midges. (Eds P.D. Armitage, P.S. Cranston \& L. V Pinder), pp. 136-198. Chapman and Hall, London.

Berggren M., Laudon H. \& Jansson M. (2007) Landscape regulation of bacterial growth efficiency in boreal freshwaters. Global Biogeochemical Cycles 21, 1-9.

Bond A.L. \& Diamond A.W. (2011) Recent Bayesian stable-isotope mixing models are highly sensitive to variation in discrimination factors. Ecological Applications 21, 1017-1023.

Bonilla S., Villeneuve V. \& Vincent W.F. (2005) Benthic and planktonic algal communities in a high arctic lake: Pigment structure and contrasting responses to nutrient enrichment. Journal of Phycology $\mathbf{4 1}$, $1120-1130$.

ter Braak C.J.F. \& Šmilauer P. (2012) CANOCO reference manual and user's guide : software for ordination (version 5.0). Biometris, Wageningen.

Brett M.T., Arhonditsis G.B., Chandra S. \& Kainz M.J. (2012) Mass flux calculations show strong Allochthonous support of freshwater Zooplankton production is unlikely. PLOS ONE 7, 1-9.

Brett M.T., Bunn S.E., Chandra S., Galloway A.W.E., Guo F., Kainz M.J., et al. (2017) How important are terrestrial organic carbon inputs for secondary production in freshwater ecosystems? Freshwater Biology 62, 833-853.

Brett M.T., Kainz M .J., Taipale S.J . \& Seshan H. (2009) Phytoplankton, not allochthonous carbon, sustains 
herbivorous zooplankton production. Proceedings of the National Academy of Sciences 106, 2119721201.

Carpenter S.R., Cole J.J., Pace M.L. \& Wilkinson G.M . (2016) Response of plankton to nutrients, planktivory and terrestrial organic matter: A model analysis of whole-lake experiments. Ecology Letters 19, 230 239.

Caut S., Angulo E. \& Courchamp F. (2009) Variation in discrimination factors $\left(\Delta^{15} \mathrm{~N}\right.$ and $\left.\Delta{ }^{13} \mathrm{C}\right)$ : the effect of diet isotopic values and appliations for diet reconstruction. Journal of Applied Ecology 46, 443-453.

Chételat J., Cloutier L. \& Amyot M . (2010) Carbon sources for lake food webs in the Canadian High Arctic and other regions of Arctic North America. Polar Biology 33, 1111-1123.

Christoffersen K.S., Jeppesen E., M oorhead D.L. \& Tranvik L.J. (2008) Food-web relationships and community structures in high-latitude lakes. In: Polar Lakes and Rivers. (Eds W.F. Vincent \& J. Laybourn-Parry), pp. 269-289. Oxford Unversity Press.

Cole J.J., Carpenter S.R., Kitchell J., Pace M.L., Solomon C.T. \& Weidel B. (2011) Strong evidence for terrestrial support of zooplankton in small lakes based on stable isotopes of carbon, nitrogen, and hydrogen. Proceedings of the National Academy of Sciences of the United States of America 108, 1975-80.

Cummins K.W. \& Klug M.J. (1979) Feeding ecology of stream invertebrates. Annual Review of Ecological Systems 10, 147-172.

Doi H., Katano I. \& Kikuchi E. (2006) The use of algal-mat habitats by aquatic insect grazers: Effects of microalgal cues. Basic and Applied Ecology 7, 153-158.

Dolédec S. \& Statzner B. (2010) Responses of freshwater biota to human disturbances: contribution of JNABS to developments in ecological integrity assessments. Journal of the North American Benthological Society $\mathbf{2 9}, \mathbf{2 8 6}-311$.

Eggermont H. \& Heiri O. (2012) The chironomid-temperature relationship : expression in nature and palaeoenvironmental implications. 87, 430-456.

Finlay J.C. \& Kendall C. (2007) Stable isotope tracing of temporal and spatial variability in organic matter 
sources to freshwater ecosystems. In: Stable Isotopes in Ecology and Environmental Science, Second. (Eds R. M ichener \& K. Lajtha), pp. 283-333. Blackwell Publishing Ltd.

France R.L. (1995) Carbon-13 enrichment in benthic compared to planktonic algae: foodweb implications. Marine Ecology Progress Series 124, 307-312.

Frossard V., Verneaux V., M illet L., Jenny J.P., Arnaud F., Magny M ., et al. (2014) Reconstructing long-term changes (150 years) in the carbon cycle of a clear-water lake based on the stable carbon isotope composition $\left(\delta^{13} \mathrm{C}\right)$ of chironomid and cladoceran subfossil remains. Freshwater Biology 59, 789-802.

Goedkoop W., Åkerblom N. \& Demandt M.H. (2006) Trophic fractionation of carbon and nitrogen stable isotopes in Chironomus riparius reared on food of aquatic and terrestrial origin. Freshwater Biology 51, 878-886.

Gregory-Eaves I. \& Beisner B.E. (2011) Palaeolimnological insights for biodiversity science: An emerging field. Freshwater Biology 56, 2653-2661.

Grey J., Kelly A. \& Jones R.I. (2004) High intraspecific variability in carbon and nitrogen stable isotope ratios of lake chironomid larvae. 49, 239-244.

Griffiths K., M ichelutti N., Blais J.M., Kimpe L.E. \& Smol J.P. (2010) Comparing nitrogen isotopic signals between bulk sediments and invertebrate remains in High Arctic seabird-influenced ponds. Journal of Paleolimnology 44, 405-412.

Hammer Ø., Harper D.A.T. a. T. \& Ryan P.D. (2001) PAST: Paleontological Statistics Software Package for Education and Data Analysis. Palaeontologia Electronica 4, 1-9.

van Hardenbroek M ., Heiri O., Grey J., Bodelier P.L.E., Verbruggen F. \& Lotter A.F. (2010) Fossil chironomid $\delta^{13} \mathrm{C}$ as a proxy for past methanogenic contribution to benthic food webs in lakes? Journal of Paleolimnology 43, 235-245.

van Hardenbroek M ., Heiri O., Parmentier F.J.W., Bastviken D., Ilyashuk B.P., Wiklund J.A., et al. (2013) Evidence for past variations in methane availability in a Siberian thermokarst lake based on $\delta^{13} \mathrm{C}$ of chitinous invertebrate remains. Quaternary Science Reviews 66, 74-84.

van Hardenbroek M., Leuenberger M., Hartikainen H., Okamura B. \& Heiri O. (2016) Bryozoan stable carbon 
and hydrogen isotopes: relationships between the isotopic composition of zooids, statoblasts and lake water. Hydrobiologia 765, 209-223.

van Hardenbroek M., Lotter A.F., Bastviken D., Duc N.T. \& Heiri O. (2012) Relationship between $\delta^{13}$ C of chironomid remains and methane flux in Swedish lakes. Freshwater Biology 57, 166-177.

Heino J. (2008) Patterns of functional biodiversity and function-environment relationships in lake littoral macroinvertebrates. Limnology and Oceanography 53, 1446-1455.

Heiri O., Schilder J. \& Hardenbroek M. Van (2012) Stable isotopic analysis of fossil chironomids as an approach to environmental reconstruction: state of development and future challenges. Fauna norvegica 31, 7-18.

Hershey a. E., Beaty S., Fortino K., Kelly S., Keyse M., Luecke C., et al. (2006) Stable isotope signatures of benthic invertebrates in arctic lakes indicate limited coupling to pelagic production. Limnology and Oceanography $\mathbf{5 1}, 177-188$.

Hobson K.A., Alisauskas R.T. \& Clark R.G. (1993) Stable-Nitrogen Isotope Enrichment in Avian Tissues Due to Fasting and Nutritional Stress: Implications for Isotopic Analyses of Diet. The Condor 95, 388.

Jansson M., Bergström A.-K., Blomqvist P. \& Drakare S. (2000) Allochthonous organic carbon and phytoplankton / bacterioplankton produciton relationships in lakes. Ecology 81, 3250-3255.

Jansson M ., Persson L., De Roos A.M ., Jones R.I. \& Tranvik L.J. (2007) Terrestrial carbon and intraspecific size-variation shape lake ecosystems. Trends in Ecology and Evolution 22, 316-322.

Johnson R.K., Goedkoop W. \& Sandin L. (2004) Spatial scale and ecological relationships between the macroinvertebrate communities of stony habitats of streams and lakes. Freshwater Biology 49, 11791194.

Jones R.I. \& Grey J. (2011) Biogenic methane in freshwater food webs. Freshwater Biology 56, 213-229. Karlsson J., Byström P., Ask J., Ask P., Persson L. \& Jansson M . (2009) Light limitation of nutrient-poor lake ecosystems. Nature 460, 506-509.

Kelly P.T., Solomon C.T., Weidel B.C. \& Jones S.E. (2014) Terrestrial carbon is a resource, but not a subsidy, for lake zooplankton. Ecology 95, 1236-1242. 
Korhola A., Olander H. \& Blom T. (2000) Cladoceran and chironomid assemblages as quantitative indicators of water depth in subarctic Fennoscandian lakes. Journal of Paleolimnology 24, 43-54.

Korhola A., Weckström J. \& Blom T. (2002) Relationships between lake and land-cover features along latitudinal vegetation ecotones in arctic Fennoscandia. Archiv für Hydrobiologie, Supplement 139, 203-235.

Luoto T.P. (2011) The relationship between water quality and chironomid distribution in Finland - A new assemblage-based tool for assessments of long-term nutrient dynamics. Ecological Indicators 11, 255262.

Luoto T.P. \& Nevalainen L. (2015) Climate-forced patterns in midge feeding guilds. Hydrobiologia 742, $141-$ 152.

Luoto T.P., Rantala M. V., Galkin A., Rautio M . \& Nevalainen L. (2016) Environmental determinants of chironomid communities in remote northern lakes across the treeline - Implications for climate change assessments. Ecological Indicators 61, 991-999.

M andaville S.M . (2002) Benthic macroinvertebrates in freshwaters: Taxa tolerance values, metrics, and protocols. Soil \& Water Conservation Society of M etro Halifax.

M arcarelli A.M., Baxter C. V, M ineau M .M . \& Hall R.O.J. (2011) Quantity and quality: unifying food web and ecosystem perspectives on the role of resource subsidies in freshwaters. Ecology 92, 1215-1225.

M cCutchan J.H., Lewis Jr W.M., Kendall C. \& M cGrath C.C. (2003) Variation in trophic shift for stable isotope ratios of carbon, nitrogen, and sulfur. Oikos 102, 378-390.

M erritt R.W., Cummins K.W. \& Berg M .B. (eds.) (2008) An introduction to the Aquatic Insects of North America, 4th edition. Kendall Hunt.

M eyers P.A. \& Teranes J.L. (2001) Sediment organic matter. In: Tracking Environmental Changed Using Lake Sediments. Volume 2: Physical and Geochemical Techniques. (Eds W.M . Last \& J.P. Smol), pp. 239-269. Kluwer Academic Publishers, Dordrecht, The Netherlands.

M ichalzik B., Kalbitz K., Park J.H., Solinger S. \& M atzner E. (2001) Fluxes and concentrations of dissolved organic carbon and nitrogen - A synthesis for temperate forests. Biogeochemistry 52, 173-205. 
M ihuc T.B. (1997) The functional trophic role of lotic primary consumers: generalist versus specialist strategies. Freshwater Biology 37, 455-462.

M inagawa M . \& Wada E. (1984) Stepwise enrichment of ${ }^{15} \mathrm{~N}$ along food chains: Further evidence and the relation between $\delta^{15} \mathrm{~N}$ and animal age. Geochimica et Cosmochimica Acta 48, 1135-1140.

Nevalainen L., Luoto T.P., Rantala M. V., Galkin A. \& Rautio M . (2015) Role of terrestrial carbon in aquatic UV exposure and photoprotective pigmentation of meiofauna in subarctic lakes. Freshwater Biology $60,2435-2444$.

Nusch E. (1980) Comparison of different methods for chlorophyll and phaeopigment determination. Archiv für Hydrobiologie 14, 14-36.

Nyman M., Korhola A. \& Brooks S.J. (2005) The distribution and diversity of Chironomidae (Insecta: Diptera) in western Finnish Lapland, with special emphasis on shallow lakes. Global Ecology and Biogeography $14,137-153$.

Parnell A. \& Inger R. (2016) Stable Isotope M ixing M odels in R with simmr. https://cran.rproject.org/web/packages/ simmr/vignettes/simmr.html

Perga M.E. (2010) Potential of $\delta^{13} \mathrm{C}$ and $\delta^{15} \mathrm{~N}$ of cladoceran subfossil exoskeletons for paleo-ecological studies. Journal of Paleolimnology 44, 387-395.

Peterson B. \& Fry B. (1987) Stable Isotopes in ecosystem studies. Annual Review of Ecological Systems 18, 293-320.

Phillips D.L., Inger R., Bearhop S., Jackson A.L., M oore J.W., Parnell A.C., et al. (2014) Best practices for use of stable isotope mixing models in. Canadian Journal of Zoology 835, 823-835.

Post D.M . (2002) Using stable isotopes to estimate trophic position: model, methods, and assumptions. Ecology 83, 703-718.

R Core Team (2017) R: A language and environment for statistical computing. https:// www.r-project.org/ Rantala M. V., Luoto T.P. \& Nevalainen L. (2016a) Temperature controls organic carbon sequestration in a subarctic lake. Scientific Reports 6, 34780.

Rantala M. V., Nevalainen L., Rautio M., Galkin A. \& Luoto T.P. (2016b) Sources and controls of organic 
carbon in lakes across the subarctic treeline. Biogeochemistry 129, 235-253.

Rautio M., Dufresne F., Laurion I., Bonilla S., Vincent W .F. \& Christoffersen K.S. (2011) Shallow Freshwater Ecosystems of the Circumpolar Arctic. Ecoscience 18, 204-222.

Rautio M . \& Vincent W.F. (2006) Benthic and pelagic food resources for zooplankton in shallow highlatitude lakes and ponds. Freshwater Biology 51, 1038-1052.

Reuss N.S., Hamerlík L., Velle G., M ichelsen A., Pedersen O. \& Brodersen K.P. (2013) Stable isotopes reveal that chironomids occupy several trophic levels within West Greenland lakes: implications for food web studies. Limnology and Oceanography 58, 1023-1034.

Seekell D.A., Lapierre J.F., Ask J., Bergström A.K., Deininger A., Rodriguez P., et al. (2015) The influence of dissolved organic carbon on primary production in northern lakes. Limnology and Oceanography 60, $1276-1285$.

Serra S.R.Q., Cobo F., Graça M .A.S., Dolédec S. \& Feio M.J. (2016) Synthesising the trait information of European Chironomidae (Insecta: Diptera): Towards a new database. Ecological Indicators 61, 282292.

Solomon C.T., Carpenter S.R., Clayton M .K., Cole J.J ., Coloso J.J., Pace M.L., et al. (2011) Terrestrial, benthic, and pelagic resource use in lakes : results from a three-isotope Bayesian mixing model. Ecology $\mathbf{9 2}$, $1115-1125$.

Solomon C.T., Carpenter S.R., Cole J.J. \& Pace M.L. (2008) Support of benthic invertebrates by detrital resources and current autochthonous primary production: Results from a whole-lake ${ }^{13} \mathrm{C}$ addition. Freshwater Biology 53, 42-54.

Solomon C.T., Jones S.E., Weidel B.C., Buffam I., Fork M .L., Karlsson J., et al. (2015) Ecosystem Consequences of Changing Inputs of Terrestrial Dissolved Organic M atter to Lakes: Current Knowledge and Future Challenges. Ecosystems 18, 376-389.

Tanentzap A.J., Kielstra B.W., Wilkinson G.M ., Berggren M., Craig N., Giorgio P.A., et al. (2017) Terrestrial support of lake food webs : Synthesis reveals controls over cross-ecosystem resource use. Science Advances 3, e1601765. 
Tranvik L.J., Downing J.A., Cotner J.B., Loiselle S.A., Striegl R.G., Ballatore T.J., et al. (2009) Lakes and reservoirs as regulators of carbon cycling and climate. Limnology and Oceanography 54, 2298-2314. Vadeboncoeur Y., Vander Zanden M.J. \& Lodge D.M . (2002) Putting the Lake Back Together: Reintegrating Benthic Pathways into Lake Food Web M odels. BioScience 52, 44-54.

Vanderklift M .A. \& Ponsard S. (2003) Sources of variation in consumer-diet $\delta^{15} \mathrm{~N}$ enrichment: A metaanalysis. Oecologia 136, 169-182.

Vanni M.J. (2002) Nutrient Cycling by Animals in Freshwater Ecosystems. Annual Review of Ecology and Systematics.

Vonk J.E., Tank S.E., Bowden W.B., Laurion I., Vincent W.F., Alekseychik P., et al. (2015) Reviews and syntheses: Effects of permafrost thaw on Arctic aquatic ecosystems. Biogeosciences 12, 7129-7167.

Walker I.R. (2001) Midges: Chironomidae and related Diptera. In: Tracking environmental change using lake sediments. Volume 4: Zoological indicators. (Eds J.P. Smol, H.J.B. Birks \& W.M. Last), pp. 43-46. Kluwer Academic Publishers, Dordrecht, The Netherlands.

Wallace J.B. \& Webster J.R. (1996) The Role of Macroinvertebrates in Stream Ecosystem Function. Annual Review of Entomology 41, 115-139.

Weishaar J.L., Aiken G.R., Bergamaschi B.A., Fram M .S., Fujii R. \& Mopper K. (2003) Evaluation of specific ultraviolet absorbance as an indicator of the chemical composition and reactivity of dissolved organic carbon. Environmental Science and Technology 37, 4702-4708.

Wooller M., Wang Y. \& Axford Y. (2008) A multiple stable isotope record of Late Quaternary limnological changes and chironomid paleoecology from northeastern Iceland. Journal of Paleolimnology $\mathbf{4 0 , 6 3 -}$ 77.

Vander Zanden M.J. \& Rasmussen J.B. (2001) Variation in $\delta^{15} \mathrm{~N}$ and $\delta^{13} \mathrm{C}$ trophic fractionation: Implications for aquatic food web studies. Limnology and Oceanography 46, 2061-2066. 


\section{Tables}

Table 1. Summary of limnological and sedimentary variables with units and abbreviations. M inimum, maximum and mean values are shown separately for lakes below and above the coniferous tree line.

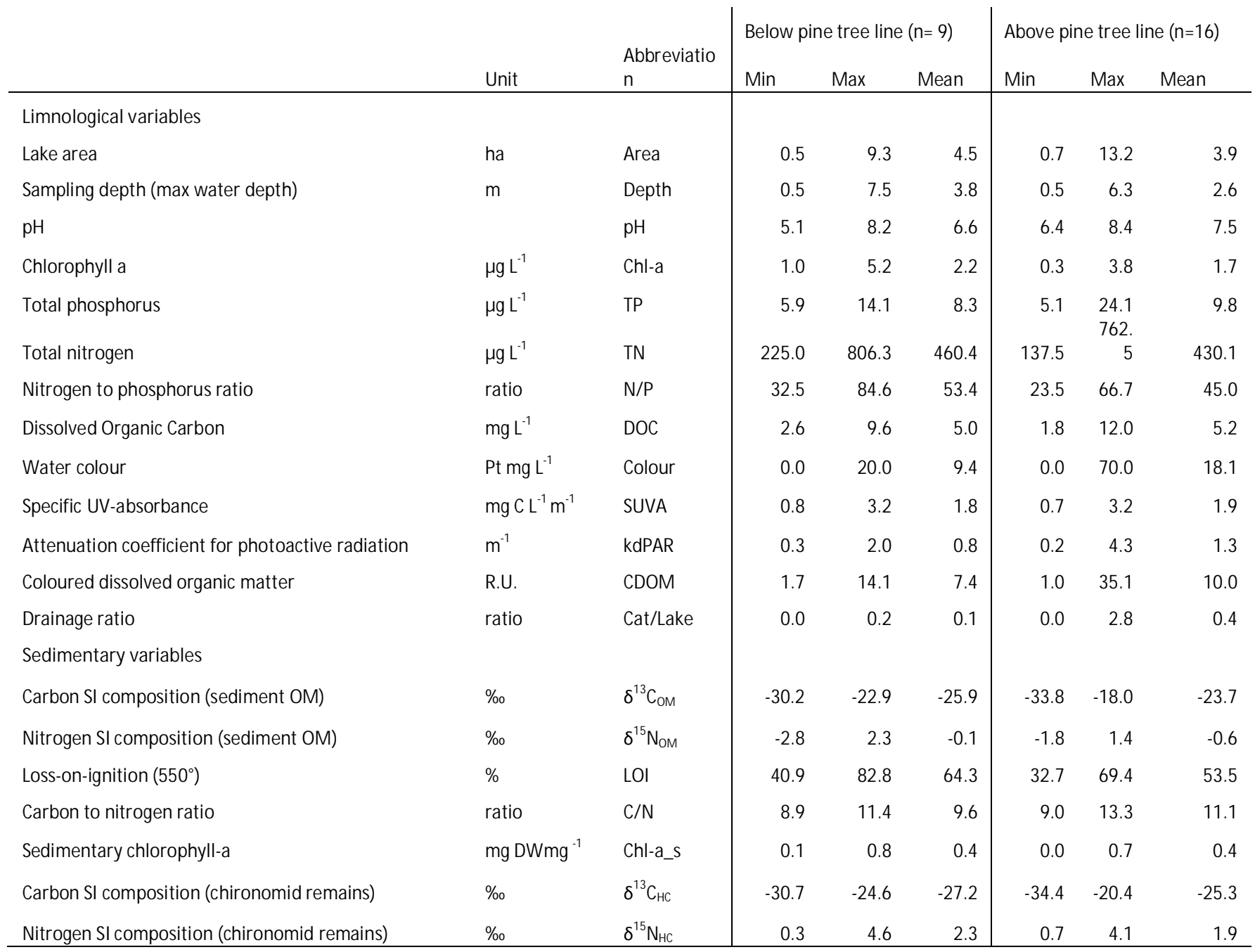


Table 2. Spearman correlation coefficients for chironomid isotopic signatures $\left(\delta^{13} \mathrm{C}_{\mathrm{HC}}, \delta^{15} \mathrm{~N}_{\mathrm{HC}}\right.$ ), sedimentchironomid offsets $\left(\Delta \delta^{13} \mathrm{C}, \Delta \delta^{15} \mathrm{~N}\right)$ and source contributions (benthic, pelagic, terrestrial) with environmental variables. For abbreviations, see Table 1 . Significant $(p<0.05)$ values are marked with bold and highly significant $(p<0.01)$ with bold italic.

\begin{tabular}{|c|c|c|c|c|c|c|c|}
\hline & \multicolumn{2}{|c|}{ Chironomid SI } & \multicolumn{2}{|l|}{ Sl offset } & \multicolumn{3}{|c|}{ Source contribution } \\
\hline Depth & -0.30 & 0.71 & -0.10 & -0.35 & -0.28 & 0.48 & -0.35 \\
\hline $\mathrm{pH}$ & 0.51 & 0.00 & 0.21 & -0.15 & 0.52 & -0.41 & -0.37 \\
\hline Chl-a & -0.44 & -0.29 & -0.28 & 0.29 & -0.47 & 0.27 & 0.39 \\
\hline TP & 0.08 & -0.56 & -0.28 & 0.18 & 0.07 & -0.21 & 0.34 \\
\hline TN & 0.01 & -0.55 & -0.41 & 0.05 & -0.02 & -0.14 & 0.45 \\
\hline $\mathrm{N} / \mathrm{P}$ & 0.01 & -0.48 & -0.12 & 0.00 & -0.02 & -0.14 & 0.37 \\
\hline DOC & -0.24 & -0.50 & -0.32 & 0.22 & -0.26 & 0.06 & 0.48 \\
\hline Colour & -0.25 & -0.26 & -0.17 & 0.13 & -0.22 & 0.12 & 0.33 \\
\hline SUVA & -0.26 & -0.14 & -0.29 & -0.05 & -0.24 & 0.15 & 0.32 \\
\hline kdPAR & -0.11 & -0.53 & -0.37 & 0.21 & -0.15 & -0.08 & 0.48 \\
\hline CDOM & -0.31 & -0.39 & -0.36 & 0.14 & -0.33 & 0.14 & 0.51 \\
\hline Cat/Lake & 0.05 & -0.12 & -0.09 & -0.03 & 0.03 & -0.14 & -0.22 \\
\hline$\delta^{13} \mathrm{C}_{\mathrm{OM}}$ & 0.98 & -0.38 & 0.56 & -0.10 & 0.99 & -0.95 & -0.22 \\
\hline$\delta^{15} \mathrm{~N}_{\mathrm{OM}}$ & -0.40 & 0.92 & -0.13 & -0.40 & -0.38 & 0.65 & -0.47 \\
\hline LOI & 0.16 & -0.51 & 0.11 & 0.15 & 0.16 & -0.27 & 0.48 \\
\hline $\mathrm{C} / \mathrm{N}$ & 0.55 & -0.25 & 0.25 & 0.34 & 0.58 & -0.50 & -0.09 \\
\hline Chl-a_s & 0.24 & -0.43 & -0.12 & 0.09 & 0.18 & -0.38 & -0.03 \\
\hline
\end{tabular}




\section{Figures}

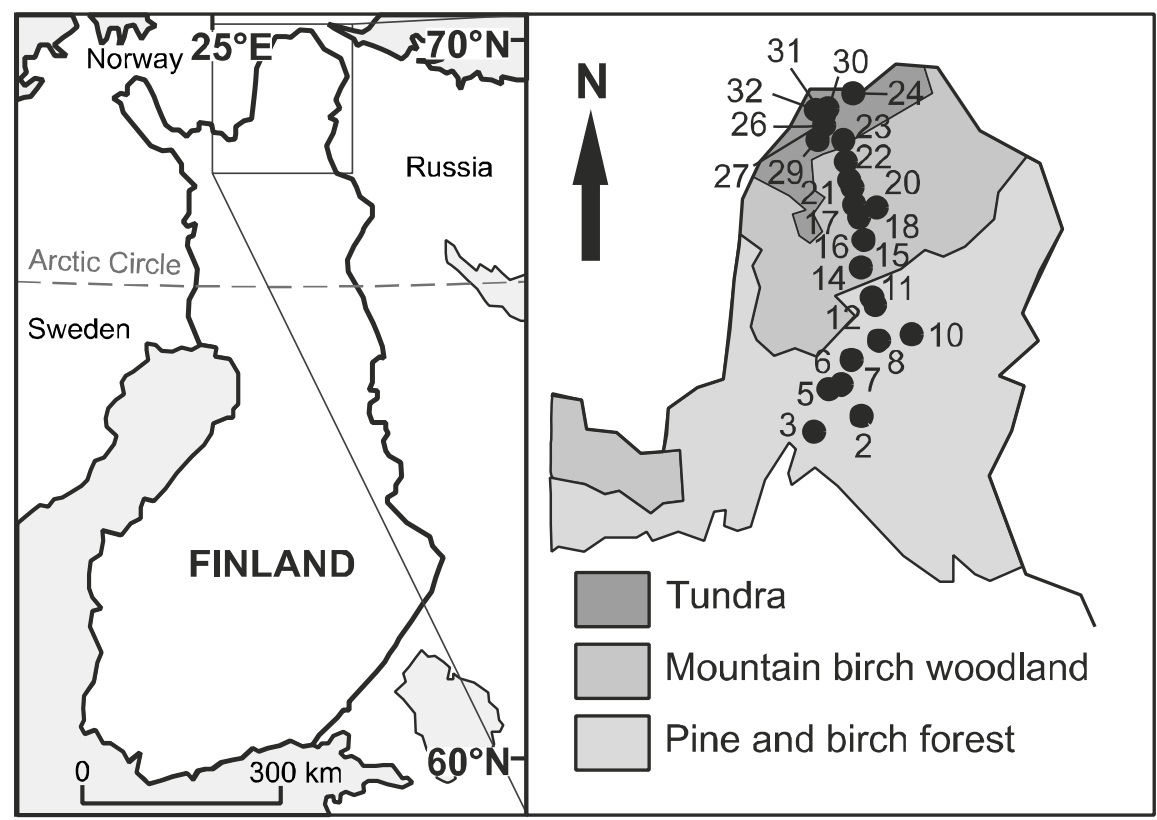

Figure 1. Map of the 25 study lakes located in northern Finland with present vegetation zones.

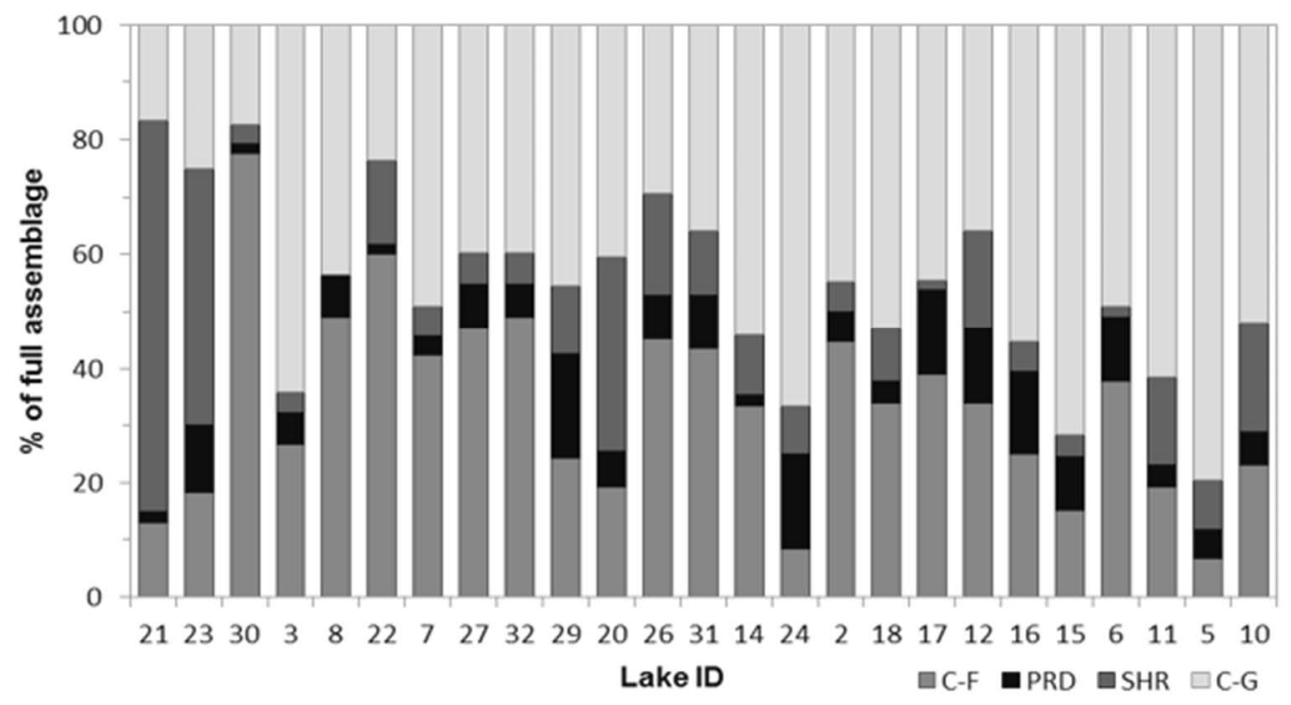

Figure 2. The relative abundance and distribution of functional assemblages in the study lakes, represented by four functional groups: collector-filterers (C-F), predators (PRD), shredders (SHR) and collectorgatherers (C-G). X-axis is scaled along increasing sediment organic matter quantity (LOI). 
A

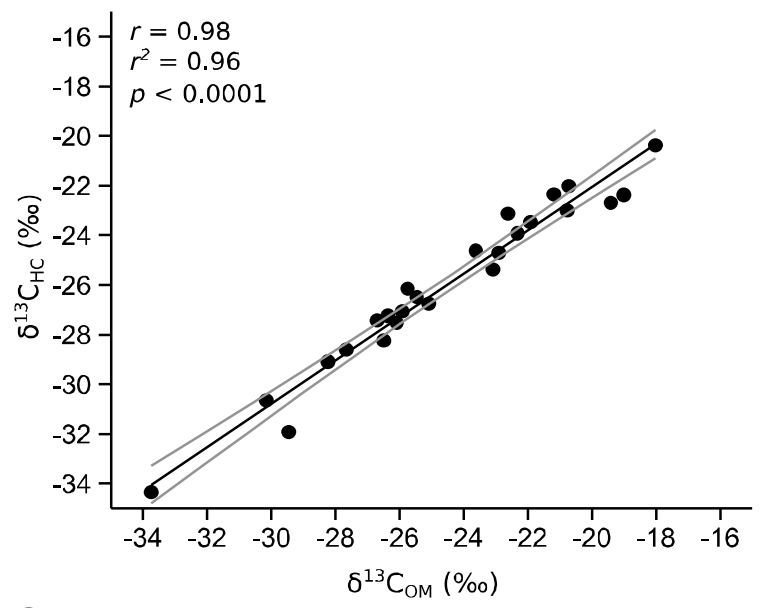

C

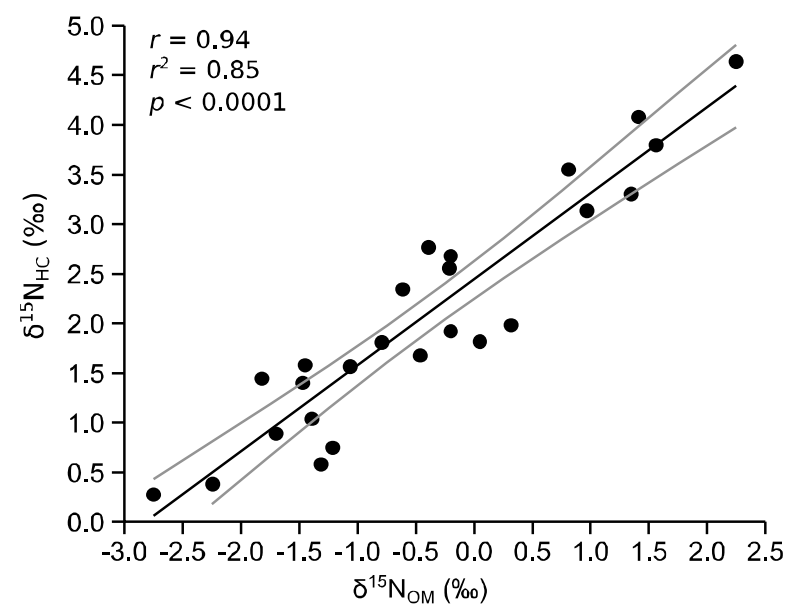

B

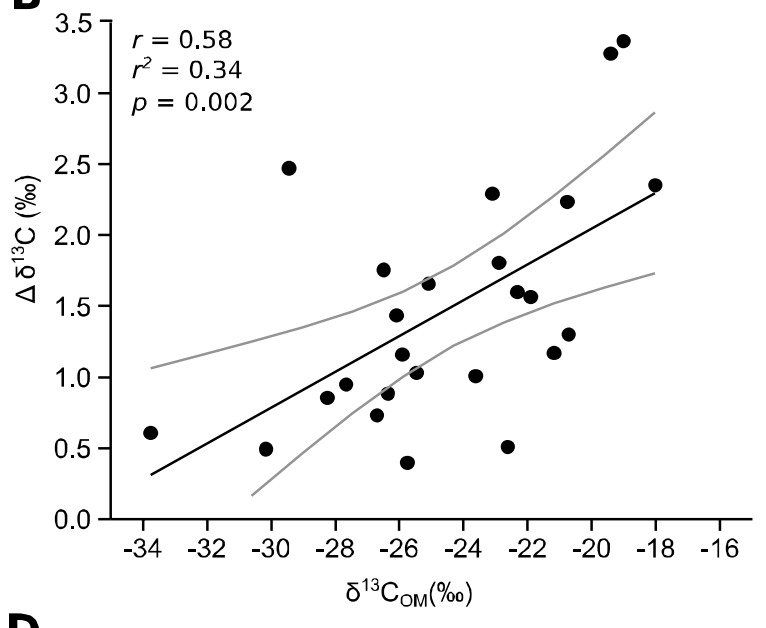

D

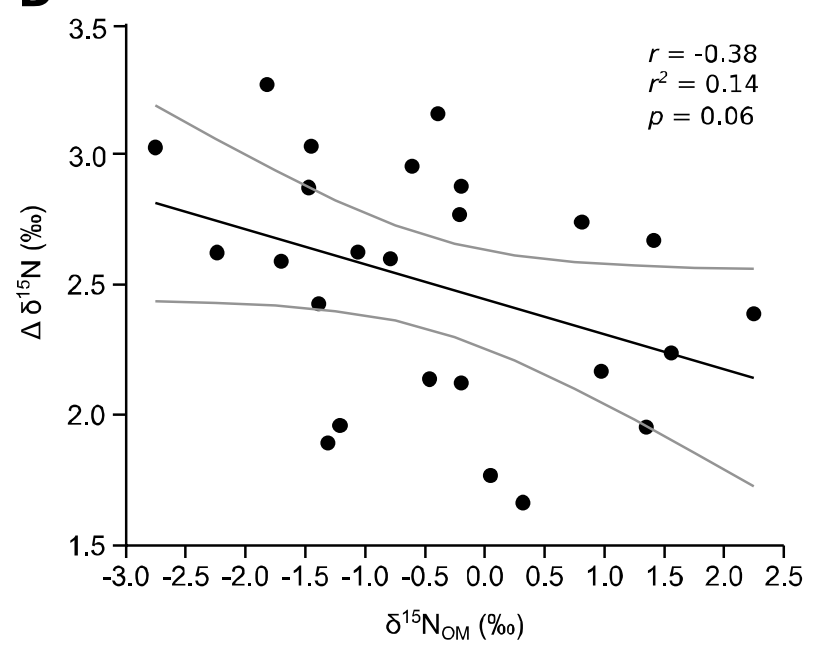

Figure 3. Linear relationships for A) carbon isotopic signature $\left(\delta^{13} \mathrm{C}\right)$ of sediment organic matter $(\mathrm{OM})$ and chironomid head capsules $(\mathrm{HC}), \mathrm{B}) \delta^{13} \mathrm{C}$ of sediment $\mathrm{OM}$ and the chironomid-sediment offset $\left.(\Delta), \mathrm{C}\right)$ nitrogen isotopic signature $\left(\delta^{15} \mathrm{~N}\right)$ of sediment $\mathrm{OM}$ and chironomid $\mathrm{HC}$ and $\left.\mathrm{D}\right) \delta^{15} \mathrm{~N}$ sediment $\mathrm{OM}$ and $\Delta \delta^{15} \mathrm{~N}$. 


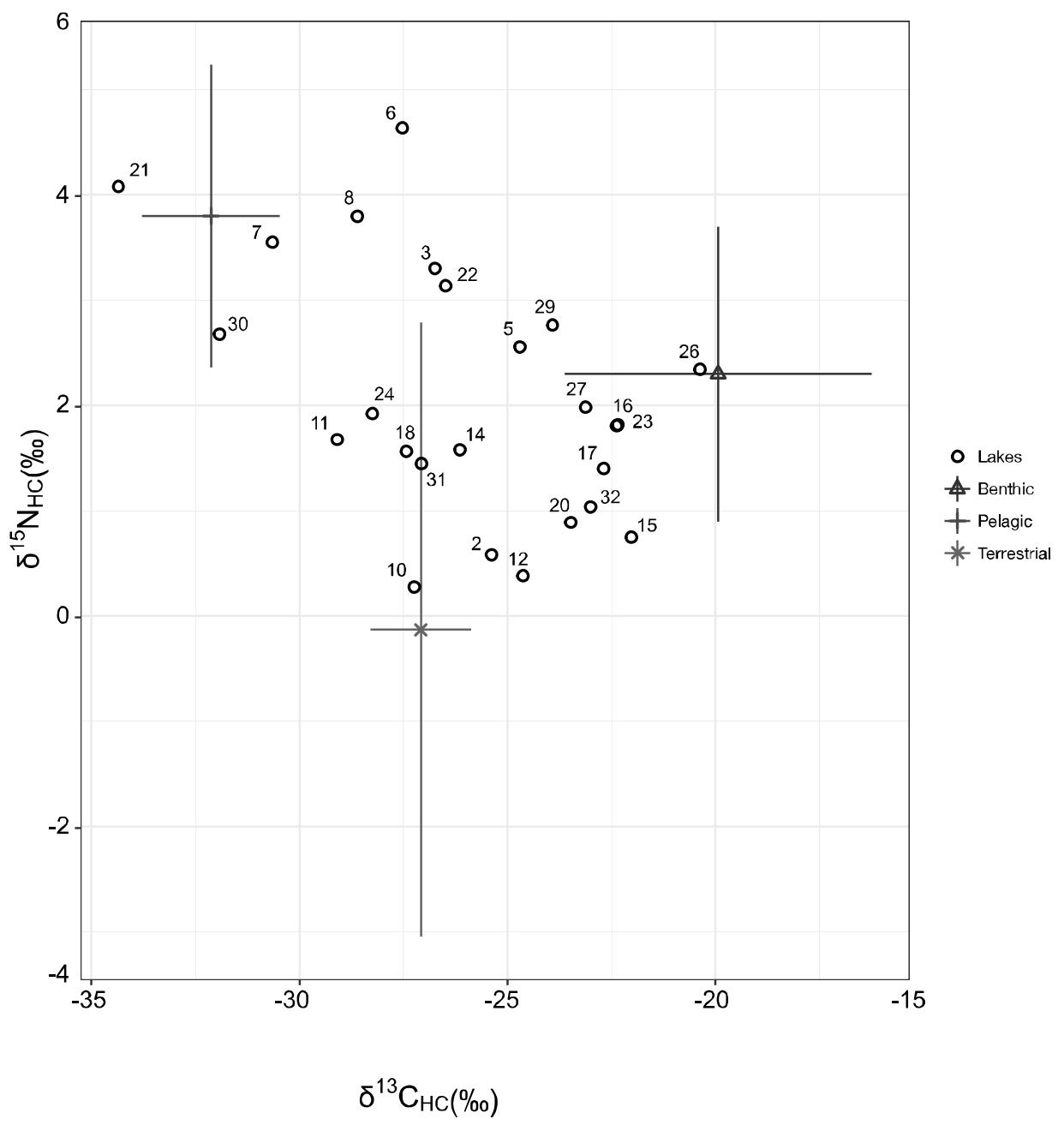

Figure 4. Isospace plot of the stable isotope mixing model. Chironomid assemblage isotope values are marked by lake ID on the plot with benthic, pelagic and terrestrial end-member estimates and their associated variability. 


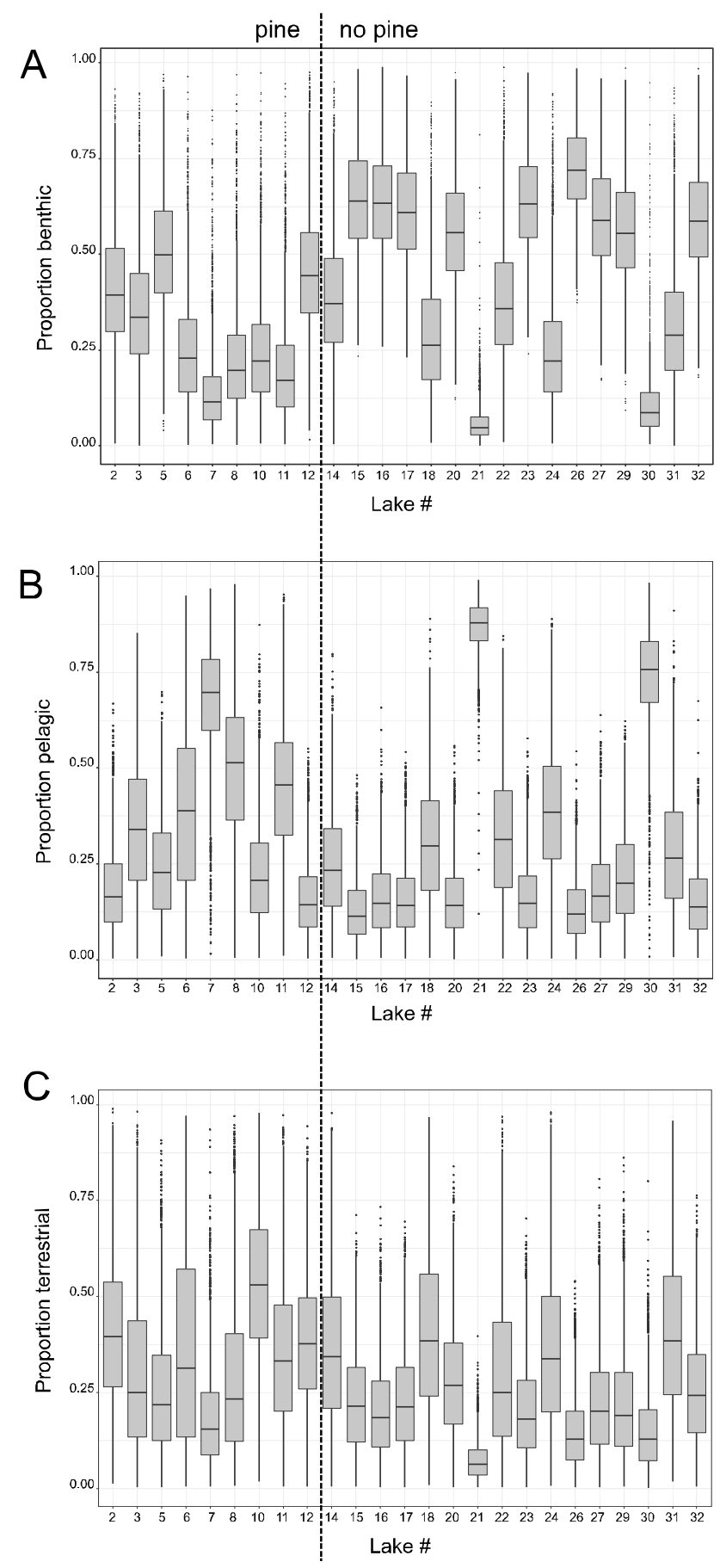

Figure 5. Relative contributions of A) benthic, B) pelagic and C) terrestrial sources for the chironomids according to the stable isotope mixing model. M ean (black line), $50 \%$ range (box) and $100 \%$ range (tails) of distribution results are presented. The vertical dashed line represents the coniferous tree line, lakes on the left are below and lakes on the right are above the tree line. 


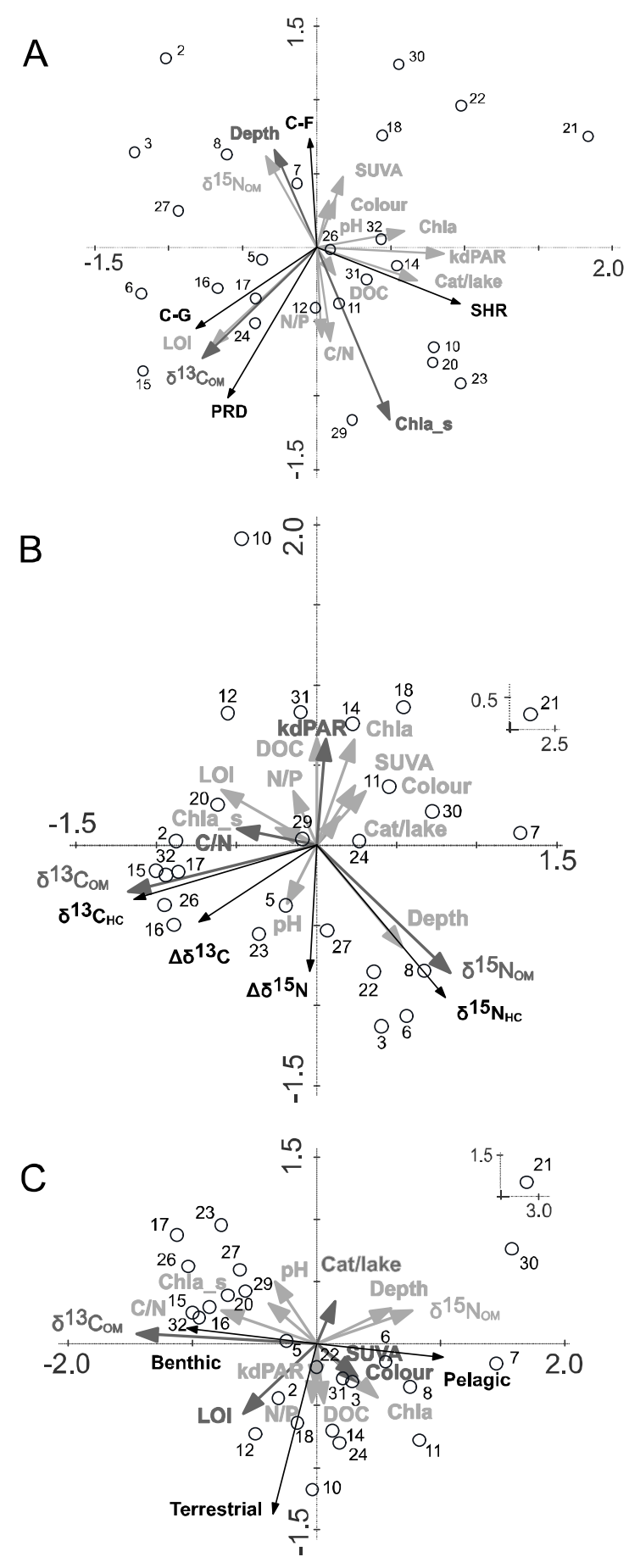

Figure 6. Redundancy analysis of A) functional feeding groups (collector-filterers (C-F), predators (PRD), shredders (SHR) and collector-gatherers (C-G)), B) chironomid stable isotope values $\left(\delta^{13} \mathrm{C}_{\mathrm{HC}}, \delta^{15} \mathrm{~N}_{\mathrm{HC}}\right)$ and sediment-chironomid offsets $\left(\Delta \delta^{13} \mathrm{C}, \Delta \delta^{15} \mathrm{~N}\right)$, and C) mean stable isotope mixing model source contributions (benthic, pelagic, terrestrial) explained with a suite of environmental variables. Lakes are represented as circles, black arrows represent the response variables, and grey the environmental variables. Dark grey arrows are variables identified significant with forward selection. For abbreviations, see table 1 . 

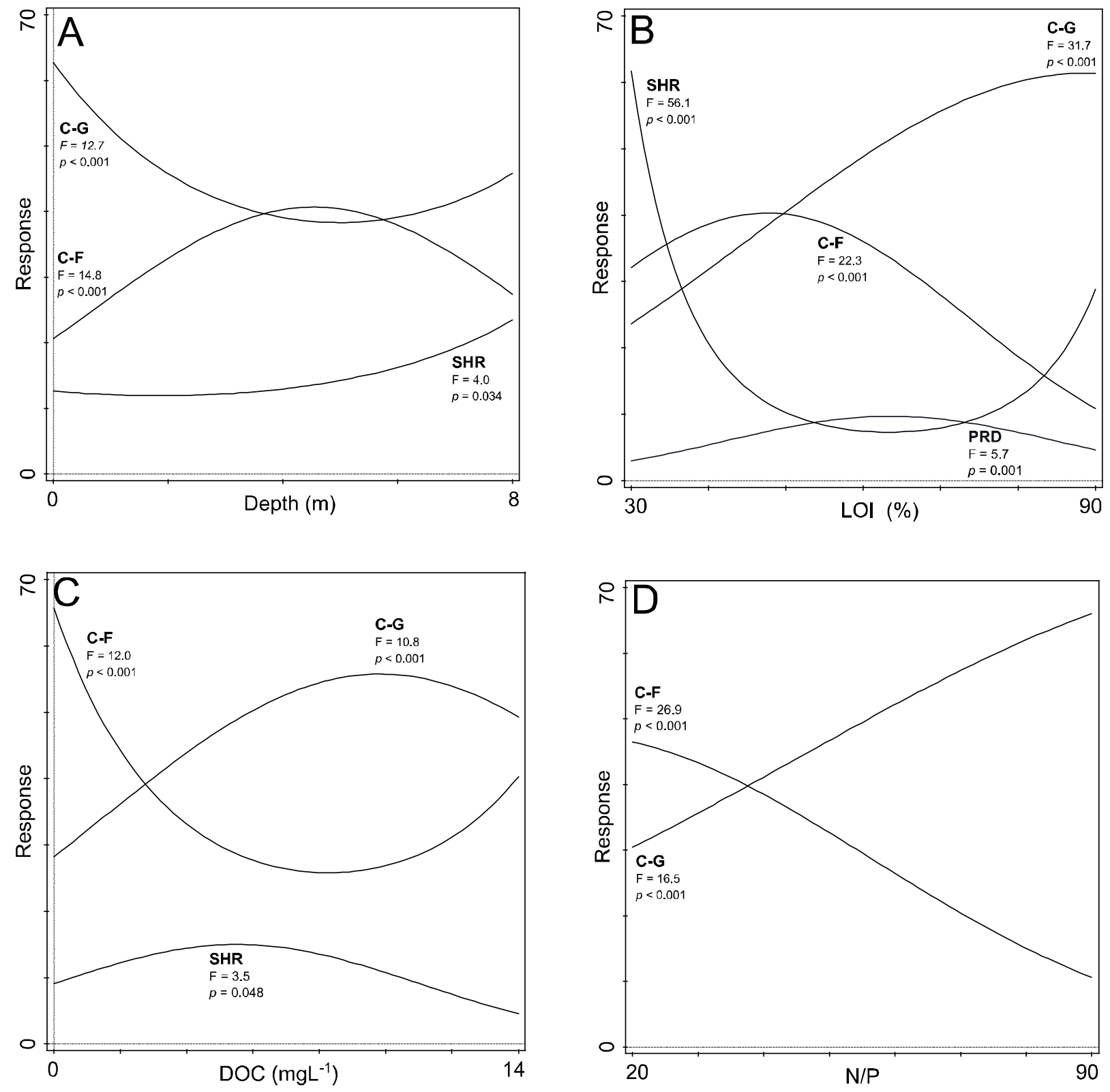

Figure 7. Response models for the functional feeding groups (gatherers C-G, filterers C-F, shredders SHR and predators PRD) and selected extrinsic variables: A) water depth, B) sediment organic matter quantity, C) dissolved organic carbon and D) N/P ratio of lake water. Only statistically significant $(p=<$ $0.05)$ responses are shown. 
Appendix 1. A list of Chironomid morphotypes assigned to different functional feeding groups (FFG)

\begin{tabular}{|c|c|c|}
\hline Morphotype & Subfamily & FFG \\
\hline \multicolumn{3}{|l|}{ Collector-filterer } \\
\hline Cladotanytarsus mancus-type & Chironominae & $c-f$ \\
\hline Corynocera ambigua & Chironominae & $c-f$ \\
\hline Corynocera oliveri-type & Chironominae & $c-f$ \\
\hline Micropsectra contracta-type & Chironominae & $c-f$ \\
\hline Micropsectra insignilobus-type & Chironominae & $c-f$ \\
\hline Micropsectra radialis-type & Chironominae & $c-f$ \\
\hline Paratanytarsus & Chironominae & $c-f$ \\
\hline Paratanytarsus austriacus-type & Chironominae & $c-f$ \\
\hline Paratanytarsus penicillatus-type & Chironominae & $c-f$ \\
\hline Rheotanytarsus & Chironominae & $c-f$ \\
\hline Tanytarsus glabrescens-type & Chironominae & $c-f$ \\
\hline Tanytarsus lactescens-type & Chironominae & $c-f$ \\
\hline Tanytarsus lugens-type & Chironominae & $c-f$ \\
\hline Tanytarsus mendax-type & Chironominae & $c-f$ \\
\hline Tanytarsus pallidicornis-type & Chironominae & $c-f$ \\
\hline Microtendipes pedellus-type & Chironominae & $c-f$ \\
\hline \multicolumn{3}{|l|}{ Collector-gatherer } \\
\hline Constempellina & Chironominae & $c-g$ \\
\hline Pseudochironomus & Chironominae & $c-g$ \\
\hline Chironomus anthracinus-type & Chironominae & $c-g$ \\
\hline Cladopelma lateralis-type & Chironominae & $c-g$ \\
\hline Demicryptochironomus & Chironominae & $c-g$ \\
\hline Dicrotendipes nervosus-type & Chironominae & $c-g$ \\
\hline Pagastiella & Chironominae & $c-g$ \\
\hline Paratendipes nudisquama-type & Chironominae & $c-g$ \\
\hline Sergentia coracina-type & Chironominae & $c-g$ \\
\hline Stictochironomus rosenschoeldi-type & Chironominae & $c-g$ \\
\hline Corynoneura arctica-type & Orthocladiinae & $c-g$ \\
\hline Heterotanytarsus & Orthocladiinae & $c-g$ \\
\hline Heterotrissocladius grimshawi-type & Orthocladiinae & $c-g$ \\
\hline Heterotrissocladius maeaeri-type & Orthocladiinae & $c-g$ \\
\hline Heterotrissocladius marcidus-type & Orthocladiinae & $c-g$ \\
\hline Hydrobaenus conformis-type & Orthocladiinae & $c-g$ \\
\hline Hydrobaenus johannseni-type & Orthocladiinae & $c-g$ \\
\hline Limnophyes & Orthocladiinae & $c-g$ \\
\hline M etriocnemus fuscipes-type & Orthocladiinae & $c-g$ \\
\hline Parakiefferiella bathophila-type & Orthocladiinae & $c-g$ \\
\hline Propsilocerus type N & Orthocladiinae & $c-g$ \\
\hline Psectrocladius (A\#) flavus-type & Orthocladiinae & $c-g$ \\
\hline
\end{tabular}


Psectrocladius ( $\mathrm{M \# )}$ barbatipes-type

Psectrocladius ( $M$ \#) calcaratus-type

Psectrocladius ( $\mathrm{M} \mathrm{\# )} \mathrm{septentrionalis-}$

type

Psectrocladius sordidellus-type

Synorthocladius

Monodiamesa

\section{Predator}

Ablabesmyia longistyla-type

Ablabesmyia monilis-type

Derotanypus

Procladius

Thienemannimyia

Cryptochironomus

Protanypus

\section{Shredder}

Polypedilum nubeculosum-type

Brillia

Cricotopus cylindraceus-type

Cricotopus (I\#) intersectus-type

Cricotopus type $P$

Zalutschia mucronata-type

Zalutschia type B

Zalutschia zalutschicola
Orthocladiinae

C-g

Orthocladiinae

c-g

Orthocladiinae

c-g

Orthocladiinae

c-g

Orthocladiinae

c-g

Diamesinae

c-g

Tanypodinae

prd

Tanypodinae

Tanypodinae

Tanypodinae

Tanypodinae

Chironominae

Diamesinae

Chironominae

Orthocladiinae

Orthocladiinae

Orthocladiinae

Orthocladiinae

Orthocladiinae

Orthocladiinae

Orthocladiinae prd

prd

prd

prd

prd

prd

shr

shr

shr

shr

shr

shr

shr

shr 
Appendix 2. Values and literature references that are used for defining end-member estimates for the stable isotope mixing model.

\begin{tabular}{|c|c|c|c|c|c|c|}
\hline \multirow{2}{*}{\multicolumn{7}{|c|}{$\begin{array}{l}\mathrm{d} 13 \mathrm{C} \% 0 \quad \mathrm{SD} \quad \mathrm{d} 15 \mathrm{~N} \% 0 \\
\text { Pelagic endmember }\end{array}$}} \\
\hline & & & & & & \\
\hline & & & & & & Eloranta, Kahilainen \& Jones \\
\hline-32.8 & 1.9 & 4.8 & 1.9 & CLAD & Saanajärvi & $\begin{array}{l}2010 \\
\text { Rautio, Mariash \& Forsström }\end{array}$ \\
\hline-31 & 0.5 & & & CLAD & Saanajärvi & $\begin{array}{l}2011 \\
\text { Jensen, Kiljunen \& Amundsen }\end{array}$ \\
\hline-29.5 & 0.8 & 4.8 & 0.8 & ZPL & Lake Fyresvatnet & $\begin{array}{l}2012 \\
\text { Thomas et al. }\end{array}$ \\
\hline-31 & 0.7 & 3.5 & 0.8 & ZPL & Inarijärvi & $\begin{array}{l}2016 \\
\text { Eloranta, Kahilainen \& Jones }\end{array}$ \\
\hline-33.3 & 4.5 & 4.5 & 1.6 & ZPL & Saanajärvi & 2010 \\
\hline-31 & 0.7 & 1.1 & 0.6 & ZPL & Lake Fyresvatnet & $\begin{array}{l}\text { Jensen et al. } 2017 \\
\text { Eloranta, Nieminen \& }\end{array}$ \\
\hline-31 & 1 & 3.8 & 0.7 & ZPL & Inarijärvi & $\begin{array}{l}\text { Kahilainen } 2014 \\
\text { Kahilainen et al. }\end{array}$ \\
\hline-30.9 & 0.2 & 3.1 & 0.3 & ZPL & Inarijärvi & $\begin{array}{l}2017 \\
\text { Kahilainen et al. }\end{array}$ \\
\hline-31.5 & 0.4 & 3.9 & 0.9 & ZPL & Muddusjärvi & $\begin{array}{l}2017 \\
\text { Kahilainen et al. }\end{array}$ \\
\hline-32.5 & 0.1 & 3.8 & 0.1 & ZPL & Paadarjärvi & $\begin{array}{l}2017 \\
\text { Kahilainen et al. }\end{array}$ \\
\hline-31.6 & 0.1 & 4.3 & 0.1 & ZPL & Kilpisjärvi & $\begin{array}{l}2017 \\
\text { Kahilainen et al. }\end{array}$ \\
\hline-33.6 & 0.03 & 3.4 & 0.1 & ZPL & Kuohkima & $\begin{array}{l}2017 \\
\text { Kahilainen et al. }\end{array}$ \\
\hline-32.4 & 0.3 & 3.8 & 0.2 & ZPL & Siilasjärvi & $\begin{array}{l}2017 \\
\text { Hayden, Harrod \& Kahilainen }\end{array}$ \\
\hline-31.8 & 1.2 & 4.5 & 1.4 & ZPL & Kilpisjärvi & $\begin{array}{l}2014 \\
\text { Eloranta et al. }\end{array}$ \\
\hline-31 & 1.5 & 3.7 & 0.7 & ZPL & Tuulisjärvi & $\begin{array}{l}2015 \\
\text { Eloranta et al. }\end{array}$ \\
\hline-31 & 2 & 2 & 1 & ZPL & Gæsjavri & $\begin{array}{l}2015 \\
\text { Eloranta et al. }\end{array}$ \\
\hline-31.5 & 0.7 & 2 & 0.2 & ZPL & Lille Rostavatn & $\begin{array}{l}2015 \\
\text { Eloranta et al. }\end{array}$ \\
\hline-32 & 0.5 & 3.5 & 0.2 & ZPL & Muddusjärvi & $\begin{array}{l}2015 \\
\text { Eloranta et al. }\end{array}$ \\
\hline-32 & 2 & 3 & 1 & ZPL & Saanajärvi & $\begin{array}{l}2015 \\
\text { Eloranta et al. }\end{array}$ \\
\hline-37 & 2 & 7.5 & 2 & ZPL & Sagelvvatn & $\begin{array}{l}2015 \\
\text { Eloranta et al. }\end{array}$ \\
\hline-32 & 2 & 3 & 1 & ZPL & Takvatn & $\begin{array}{l}2015 \\
\text { Eloranta et al. }\end{array}$ \\
\hline-31 & 0.7 & 4 & 0.2 & ZPL & Inarijärvi & $\begin{array}{l}2015 \\
\text { Eloranta et al. }\end{array}$ \\
\hline $\begin{array}{l}-32 \\
-325\end{array}$ & $\begin{array}{c}0.2 \\
2\end{array}$ & $\begin{array}{l}3 \\
4\end{array}$ & $\begin{array}{l}0.2 \\
0.7\end{array}$ & $\begin{array}{l}Z P L \\
7 P I\end{array}$ & $\begin{array}{l}\text { Vuolit spielgajavri } \\
\text { Bigaiiavri }\end{array}$ & $\begin{array}{l}2015 \\
\text { Floranta et al }\end{array}$ \\
\hline
\end{tabular}


Eloranta et al.

2015

Eloranta et al.

2015

Eloranta et al.

2015

$\begin{array}{lllll}-34 & 2 & 2.5 & 0.7 & \text { ZPL }\end{array}$

Fjellfrøsvatn

Eloranta et al.

2015

$\begin{array}{lllll}-32 & 0.7 & 4 & 0.2 & \mathrm{ZPL}\end{array}$

Rahajärvi

Eloranta et al.

$\begin{array}{lllll}-32 & 0.2 & 3 & 0.7 & \mathrm{ZPL}\end{array}$

Datkujvari

2015

Eloranta et al.

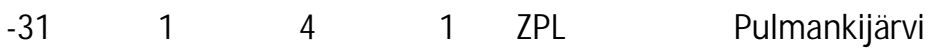

2015

Eloranta et al.

Kilpisjärvi 2015

\begin{tabular}{ccccl}
-32 & 0.7 & 4 & 0.2 & ZPL \\
\hline $\mathbf{- 3 2 . 1}$ & $\mathbf{1 . 1}$ & $\mathbf{3 . 8}$ & $\mathbf{0 . 7}$ & M EAN \\
$\mathbf{1 . 6}$ & $\mathbf{0 . 9}$ & $\mathbf{1 . 3}$ & $\mathbf{0 . 5}$ & STD \\
\hline
\end{tabular}

\section{Benthic endmember}

\begin{tabular}{|c|c|c|c|c|c|c|}
\hline-24.4 & 1 & 2.5 & 1 & B. MAT & Masi & 2011 \\
\hline-24.2 & 0.5 & -0.8 & 0.1 & B. MAT & Boat & $\begin{array}{l}2011 \\
\text { Mariash et al. }\end{array}$ \\
\hline-27 & 0.2 & -0.2 & 0.4 & B. MAT & Big rock & $\begin{array}{l}2011 \\
\text { M ariash et al. }\end{array}$ \\
\hline-23 & 0.5 & -0.1 & 0.1 & B. MAT & Happy & $\begin{array}{l}2011 \\
\text { M ariash et al. }\end{array}$ \\
\hline-19.5 & 2.7 & 0.5 & 0.4 & B. MAT & North Malla & $\begin{array}{l}2011 \\
\text { Mariash et al. }\end{array}$ \\
\hline-15.7 & 1.5 & 0.3 & 0.5 & B. MAT & South Malla & $\begin{array}{l}2011 \\
\text { M ariash et al. }\end{array}$ \\
\hline-16.4 & 1.3 & -1.1 & 0.1 & B. MAT & Reindeer & $\begin{array}{l}2011 \\
\text { Mariash et al. }\end{array}$ \\
\hline-19 & 1 & 0.8 & 0.8 & B. MAT & Lampo & $\begin{array}{l}2011 \\
\text { M ariash et al. }\end{array}$ \\
\hline-21.4 & 2 & -1.4 & 1 & B. MAT & Tuono & $\begin{array}{l}2011 \\
\text { M ariash et al. }\end{array}$ \\
\hline-17 & 1.5 & 1 & 1 & B. MAT & Straca & $\begin{array}{l}2011 \\
\text { Eloranta, Kahilainen \& Jones }\end{array}$ \\
\hline-21.6 & 4.3 & 1.1 & 0.6 & BIOFILM & Saanajärvi & $\begin{array}{l}2010 \\
\text { Kahilainen et al }\end{array}$ \\
\hline-28 & & 3.7 & & BIOFILM & Inarijärvi & $\begin{array}{l}2017 \\
\text { Kahilainen et al }\end{array}$ \\
\hline-17.5 & & 1.3 & & BIOFILM & Muddusjärvi & $\begin{array}{l}2017 \\
\text { Kahilainen et al }\end{array}$ \\
\hline-20.8 & 2.5 & 2 & 0.6 & BIOFILM & Paadarjärvi & $\begin{array}{l}2017 \\
\text { Kahilainen et al }\end{array}$ \\
\hline-18 & 0.2 & 1.8 & 1 & BIOFILM & Kilpisjärvi & $\begin{array}{l}2017 \\
\text { Kahilainen et al }\end{array}$ \\
\hline-17.7 & & -0.4 & & BIOFILM & Kuohkima & $\begin{array}{l}2017 \\
\text { Kahilainen et al }\end{array}$ \\
\hline $\begin{array}{l}-24.4 \\
-24.7\end{array}$ & 0.3 & 0.9 & 0.3 & $\begin{array}{l}\text { BIOFILM } \\
\text { EPILITHOS }\end{array}$ & $\begin{array}{l}\text { Siilasjärvi } \\
\text { Lake Almberga }\end{array}$ & $\begin{array}{l}2017 \\
\text { Karlsson, Ask \& Jansson } 2008\end{array}$ \\
\hline $\begin{array}{c}-21.1 \\
3.7\end{array}$ & $\begin{array}{l}1.4 \\
1.1\end{array}$ & $\begin{array}{l}0.7 \\
1.3\end{array}$ & $\begin{array}{l}0.6 \\
0.3\end{array}$ & $\begin{array}{l}\text { MEAN } \\
\text { STD }\end{array}$ & & \\
\hline
\end{tabular}




\begin{tabular}{|c|c|c|c|c|c|c|}
\hline-27 & & & & C3 plant & Global & M arshall, Brooks \& Lajtha 2007 \\
\hline-28 & 0.8 & & & SOIL & Njakajaure & Rosen et al. 2009 \\
\hline-26.5 & 0.6 & & & SOIL & Ohio & $\begin{array}{l}\text { Weber et al. } 2017 \\
\text { Jonsson \& }\end{array}$ \\
\hline-29.73 & 2.31 & 0.99 & 2.11 & LITTER & Västerbotten & $\begin{array}{l}\text { Stenroth } 2016 \\
\text { Syväranta et al. }\end{array}$ \\
\hline-29 & 0.8 & -0.5 & 0.4 & LITTER & Gollinsee & $\begin{array}{l}2016 \\
\text { Syväranta et al. }\end{array}$ \\
\hline-29.5 & 1.2 & -1.3 & 0.3 & LITTER & Schultzensee & $\begin{array}{l}2016 \\
\text { Cole \& Solomon }\end{array}$ \\
\hline \multirow[t]{7}{*}{-28.5} & 1 & 0.3 & 1 & LITTER & Hudson river & $\begin{array}{l}2012 \\
\text { Nadelhoffer et al. }\end{array}$ \\
\hline & & -3 & 0.5 & LEAF & Toolik & $\begin{array}{l}1996 \\
\text { Nadelhoffer et al. }\end{array}$ \\
\hline & & -6 & 0.5 & LEAF & Toolik & $\begin{array}{l}1996 \\
\text { Nadelhoffer et al. }\end{array}$ \\
\hline & & 2 & 0.5 & LEAF & Toolik & $\begin{array}{l}1996 \\
\text { Nadelhoffer et al. }\end{array}$ \\
\hline & & 2 & 0.3 & LEAF & Sag River & $\begin{array}{l}1996 \\
\text { Nadelhoffer et al. }\end{array}$ \\
\hline & & -5 & 0.5 & LEAF & Sag River & $\begin{array}{l}1996 \\
\text { Nadelhoffer et al. }\end{array}$ \\
\hline & & -6 & 0.5 & LEAF & Sag River & 1996 \\
\hline-28 & 1.25 & -2.5 & 3 & LEAF & W Greenland & Reuss et al. 2013 \\
\hline-28.3 & 1.1 & -1.7 & 0.9 & MEAN & & \\
\hline 1.1 & 0.5 & 2.9 & 0.8 & STD & & \\
\hline
\end{tabular}

Abbreviations: $\mathrm{CLAD}=$ cladoceran, $\mathrm{ZPL}=$ zooplankton (bulk), $\mathrm{B}$. M AT = benthic bacterial mat, BIOFILM =benthic biofilm, EPILITHOS = epilithic algae, SOIL = organic soil C, LITTER = aged leaf litter, LEAF = alive vegetation 